\title{
Emrî Divanı'nda Deyimler
}

HASAN KAYA*

\author{
The Idioms In Emri's Divan
}

Ö Z E T

Klasik Türk edebiyatı şairlerinin divanları deyimlerin çokça yer aldı̆̆ı önemli eserlerdir. XVI. yüzyıl şairi Emrî (ö. 1575)'nin Divan da deyim zenginliği bakımından dikkat çekicidir. Bu makalede Emrî Divani'nda 541 farkl deyimin toplam 1031 defa kullanıldığı tespit edilmiştir. Bu deyimlerin Divan'da geçtiği yerler belirtilmiş, deyimlerin bazılarına örnekler verilmiştir. Şairin kullandığı deyimlerde görülen özellikler ile deyimlerin anlamları ortaya konmuştur..

A N A H T A R K E L İ M E L E R

Klasik Türk edebiyatı, XVI. yüzyıl, Emrî Divanı, deyimler.
A B S T R A C T

The divans of classical Turkish literature poets are important works in which idioms can be seen very often. The Divan of the poet of $16^{\text {th }}$ century Emri who dead in 1575 is noteworthy in terms of abundance. In this article, it was found that 541 different idioms had been used 1031 times in the aggregate. The place of idioms in Divan was brought out, examples were given for some idioms. The features of idioms that the poet used and the meanings of had been introduced.

\section{K E Y W O R D S}

Classical Turkish literature, $16^{\text {th }}$ century, The Divan of Emri, idioms.

\section{GİRIŞ̧}

“Genellikle gerçek anlamından az çok ayrı, ilgi çekici bir anlam taşıyan kalıplaşmış anlatım, tabir (Türkçe Sözlük 1998: I/576); bir kavramı, bir durumu, ya çekici bir anlatımla ya da özet bir yapı içinde belirten ve çoğunun gerçek anlamlarından ayrı bir anlamı bulunan kalıplaşmış sözcük topluluğu ya da tümce (Aksoy 1988: I/52); en az iki söz varlığından oluşan ve gerçek anlamları dışında mecazî anlam ile pekiştirilmiş bulunan kalıplaşmış söz öbeği ya da deyiş (Parlatır 2010: I/1); anlatıma ak1cılık, çekicilik katan, çoğunun gerçek anlamından ayrı bir anlamı bulunan, genellikle de birden çok sözcüklü dil ögesi, kalıplaşmış sözcük topluluğu (Püsküllüoğlu 2006: 7); ekseriya birkaç kelime, bazen tam veya noksan bir cümle ile meramı anlatmaya yarayan; teşbih, istiare, mecaz, kinaye unsurlarıyla bir şeyi, bir hadiseyi tasvir ve ifade için kullanılan sözler (Millî Kütüphane Başkanlığ1 1997: I/VII)" şeklindeki ta-

Dr., Manisa Hasan Türek Anadolu Lisesi Edebiyat Öğretmeni, Manisa (hasanka84@hotmail.com). 
nımlarda öne çıan; deyimin iki veya daha çok sözcükten oluşması, mecazlı ve özlü bir anlatıma sahip olması ve kalıplaşmasıdır.

\section{I.1.Divan Şiirinde Deyimler}

Pek çok divan şairinin divanında deyimler geniş yer tutar. Buna rağmen divan edebiyatı metinleri deyimler bakımından yeteri kadar incelenmemiştir. Son yıllarda, giderek artan bir biçimde bu metinlerde yer alan deyimlerle ilgili çalışmaların yapıldığını da belirtmeliyiz. ${ }^{1} \mathrm{Bu}$

${ }^{1}$ Deyimlerle ilgili bazı çalışmalar için bk. H. Dilek Batislam, “Nedim'in Şiirlerindeki Atasözleri ve Deyimler", Türkoloji Araştırmaları Dergisi, Fuat Özdemir Anısı, 1997, s. 107-123; Hatice İçel, "Necatî Beg Divanı'ndaki Deyimler", Türklük Bilimi Araştırmaları Dergisi, S. 15, 2004, s. 175-230; Mustafa Aksoy, "XVI. Yüzyıl Şuarâ Tezkireleri ile Necâtî́nin Şiirlerine Göre Anadolu Türk Edebî Dilinin Gelişiminde Deyim ve Atasözü Kullanımı", SDÜ Fen Edebiyat Fakültesi Sosyal Bilimler Dergisi, S. 16, 2007, s. 141-162; Dilek Erenoğlu, "Güvâhî'den Günümüze Atasözleri ve Deyimler", Turkish Studies, S. 2/4, 2007, s. 1150-1167; Mehmet Ulucan, "Muvakkitzade Mehmed Pertev'in Divanında Atasözleri ve Deyimlerin Kullanımı", Fırat Üniversitesi İlahiyat Fakültesi Dergisi, 10:2, 2005, s. 49-80; Ülkü Çetinkaya, "Divan Şiirinde Çok Başlu (Ziyade-Ser) Deyimi Üzerine", Turkish Studies, S. 4/2, 2009, s. 226-245; Ozan Y1lmaz, "Klasik Türk Edebiyatı́nda Bir Deyim: Ter Düşmek", Türk Kültürrü İncelemeleri Dergisi, S. 21, 2009, s. 155-170; Yunus Kaplan, "Sâbit'in Şiirlerinde Atasözleri, Deyimler ve Halk Söyleyişleri", Turkish Studies, S. 4/4, 2009, s. 599-635; M. Ziya Bağriaçık, "Yerel Malzemeyi Önemseyen Bir Şair: Ahmed-i Dâi (Divanında Kullandığı Atasözleri ve Deyimler", Turkish Studies, S. 4/5, 2009, s. 60-75; M. Nejat Sefercioğlu, "Helâkî Divanı'nda Türkçe Deyimler", Divan Edebiyatı Araştırmaları Dergisi, S.4, 2010, s. 155-202; Yakup Poyraz-Ayhan Tergip, "18. Yüzyll Dîvân Şairlerinden Hâkim'in Şiirlerinde Atasözleri, Deyimler ve Halk Söyleyişleri", Uluslararası Sosyal Araştırmalar Dergisi, Klâsik Türk Edebiyatının Kaynakları Özel Sayısı, Prof. Dr. Turgut Karabey Armağanı, S. 3/15, s. 188-202; Sevil Öge, 15. Yüzyll Şairlerinden Mesihî, Cem Sultan, Ahmed Paşa, Necatî Beg, Üsküblü İshak Çelebi ve Şeyhînin Divanlarında Atasözleri ve Deyimler, Trakya Üniversitesi Sosyal Bilimler Enstitüsü, Yayımlanmamış Yüksek Lisans Tezi, Edirne 2001; Melih Alptekin, Garib-nâme'de Deyimler ve Atasözleri, Yüzüncü Yıl Üniversitesi Sosyal Bilimler Enstitüsü, Yayımlanmamış Yüksek Lisans Tezi, Van 2003; Nursel Uyanıker, Pervâne Beğ Mecmuasmnn İlk Yüz Varağında (1a-100b) Halk Kültürü̈ ile İlgili Unsurlar (Atasözleri-Deyimler-Halk İnanışları), Marmara Üniversitesi Türkiyat Araştırmaları Enstitüsü, Yayımlanmamış Yüksek Lisans Tezi, İstanbul 2006; Devrim Kalaycı Sevinç, 18. Yüzyıl Şairlerinden Sünbülzade Vehbi (Lutfiyye), Bosnalı Sabit, Enderunlu Vasıf ve Nedim'in Divan ve Mesnevilerinde Atasözleri ve Deyimler, Trakya Üniversitesi Sosyal Bilimler Enstitüsü, Yayımlanmamış Yüksek Lisans Tezi, Edirne 2007. 
çalışmaların artması Türkçenin deyim zenginliğinin ortaya konması bakımından önemlidir. Çünkü bu makalede de görüleceği gibi divan şairlerinin kullandığı kimi deyimler kapsamlı deyim sözlüklerinde bile henüz yer almamaktadır. Divan şiirine özgü deyimleri içeren müstakil sözlüklerin hazırlanmasında da yarar olduğunu düşünmekteyiz. Henüz bu alanda yapılan çalışmalar sınırlı düzeydedir. Divan şairlerinin eserlerinde deyimler üzerine yapılacak çalışmalar istenilen düzeye eriştiğinde bu, bundan sonraki sözlük çalışmalarına önemli ölçüde kaynak sağlayacaktır. Bu makalenin amaçlarından biri de budur.

\section{I.2. Emrî Divanı'nda Yer Alıp Deyim Sözlüklerinde Yer Almayan Deyimler}

Emrî Divanı'nda tespit edebildiğimiz deyimlerin anlamlarını ortaya koyarken deyimler konusunda söz sahibi temel kaynaklara müracaat ettik. Ancak deyim olduğunu düşündüğümüz bazı kalıpların müracaat ettiğimiz bu kapsamlı kaynaklarda yer almadığını gördük. Bu kalıplar şunlardır: Akçası kızıl çıkmak, aklı terk etmek, başı devletli, başına bela gelmek, başından yumruk indirmemek, baştan gitmemek, berk yüzlü, boğazını çengelde görmek, boğazını urganda bulmak, dudă̆ım dişlemek, elden uçurmak, gönlüne getirmek, gözü önünde, hiçe gitmek, ırkını kesmek, kana yumak, kanlı, kazaya uğramak, kendi gözündeki çöpü görmek, kendini bilmez, kılıç tartmak, kulă̆a düşmek, kulă̆ına çalmak, kulağına parmak tıkamak, kulağını yemek, kulaktan âşı etmek, kulpu elinde kalmak, mata yakın olmak, nazar dokundurmak, nefese uğramak, oyun gözetmek, ölüsü yasına (şivenine) değmemek, ön vermemek, pahası bir pul, pahasına akçe saymak, parmağına değmemek, rüyasında (ancak) görmek, söz değmemek, söz kaçırmak, sözüne değmek, sözünün nereye gittiğini bilmemek, şişip kabarmak, taş altında kalsın, toprak (hâk) etmek, üstüne kalkmak, yaban oğlanı, yıldızı alışmamak, yoluna dökmek, yolunda pâymâl olmak, yolunda toprak (hâk) olmak, zerreye saymamak, zevali gelmek.

\section{I.3. Deyim Sözlüklerinin Sadece Bir Tanesinde Yer Alan Deyimler}

Ayrıca bazı deyimlerin müracaat edilen kaynakların "sadece bir tanesinde" yer aldığı görülmüştür. Bu deyimlerin de sayısı az değildir: Acı 
dil vermek, aklından geçmek, aklını aldırmak, ayă̆ımı almak, ayağını pek basmak, ayak bastırmamak, bağrı kan (hûn) olmak, bağrı kebap etmek, bağrını kan (hun) etmek, başını kavgaya vermek, bıçağa düşmek, bir giydiğini bir daha giymemek, bir nice, can borcu, dokuz dolanmak, el uzunluğu eylemek, elden ayağa düşmek, elinden kapmak, elini göğsüne koymak, elif çekmek, ezber(e) okumak, gama düşmek, gen yakadan, göğsünü dövmek, gönüllü gönülsüz, gözden savmak, gözyaşını silmek, harca sürmek, hisse almak, içi dışına uymamak, ikrar eylemek, iş asmak, kan bahasını almak, kanına hat getirmek, kanına kast etmek, kanımı helal etmek, kanımı yerde komamak, kara bahtlı, kara gönüllü, kara yă̆ız, kef geçmek, kendini bilmemek, kendini yüksekte tutmak, kılıç bıçak olmak, kul etmek, kulak çekmek, kulak urmak, nakış geçmek, nal kesmek, nazına katlanmak, ortaya almak, reng eylemek, reng geçmek, sabaha diri çıkmak, sevdaya salmak, siper almak, tâkati yetmemek, taş üstünde taş kalmamak, ter düşmek/düşürmek, yakayı kurtaramamak, yalın yüzlü, yaşı kurumak, yükünü çekmek, yüz dürmek, yüzü sulu, zebunu olmak.

\section{I.4. Emrî̀nin Edebî Yönü}

Emrî Divani'nda 2 kaside, 1 murabba', 1 muhammes, 1 müsemmen, 2 tahmis, 1 müstezad, 572 gazel, 493 mukattaat ve 1 tarih manzumesi vardır. Daha çok muammaları ve tarih düşürmedeki ustalığıyla tanınan Emrî́nin önemli bir özelliği de kurguladığı ince hayaller ve bulduğu bakir manalardır. Tezkireler Emrî'den övgüyle söz eder (Saraç 1997: 323328; Saraç 1995: XI/164). Şairin ince hayal ve söylenmemiş anlamlara ulaşırken dili güzel ve etkili kullanması, dile hâkim oluşu özellikle belirtilmelidir. Emrî, yabancı kelimeleri kullanmanın yanında Türkçe kelimelere özel önem vermiştir. Divanı'nda arkaik dediğimiz bugün kullanılmayan ancak o dönem Türkçesinde yer alan "ă̆-, argaç, arış, belinle( $t$ )-, biliş-, burg-, burtar-, çel-, depren-, dirgür-, döy-, düg-, egir-, eyegüsi, eyit-, genez, gijgur-, göger-, gönile-, göynük, göyün-, ır-, ışılat-, ilin-,ilt-,kanı-, kımra-, kuc-, öykün-, sagrak, sanç-, sesel-, ses-, st-, söyün-, tapşır-, üş-, yarag, yegin, yel-, yil-, yon-, yör-" gibi pek çok kelimeyi kullanması önemli bir özelliktir. Emrî̀nin bir diğer özelliği şiirlerinin devri ile alakalı örf ve âdetleri, günlük hayat ile alakalı birçok hususu aksettirmesidir (Saraç 1997: 331). Yukarıda ifade edildiği gibi ince hayal ve söylenmemiş anlamları yakalayan şairin en önemli yardımcısı dildir. Şair özellikle de- 
yimlerin anlam zenginliğinden yararlanmış, deyimin mecaz dünyasının yanında, o mecazın gerçek anlamını da çağrıştıracak şekilde kinaye sanatının güzel örneklerini vermiştir. Bu, Emrî’nin Türkçeye hâkim olduğunun önemli bir göstergesidir.

\section{I.5. Deyimi Oluşturan Kelimelerde Yer Değiştirme}

Emrî Divanı'nda deyimlerin önemli özelliklerinden biri, deyimlerin kalıplaşmış yapılarının birçok divan şairinde görüldüğü gibi vezin ve kafiye zaruretiyle değişmesidir. Yapısal değiştirmenin bir örneği deyimi devrik yapıda kullanmadır. Devrik yapının ilk örneği iki kelimeden oluşan bir deyimin ikinci kelimesini önceleme, yani başa alma şeklinde karşımıza çıkar: "İdinsün âdet (G.399/4); alur agzına (G.35/5); almasun agzına (M.346/1); tuta gör agızların (M.224/2); aldurdı 'aklın (M.456/2); girer araya (Tah.2/III); virüp arka (G.546/3); düşdi ayaga (G.483/2), düşdüm ayaklara (G.385/1), düşdi ayagına (M.331/1); götürdüm ayagı (M.7/2); basalum bagrumuza (G.557/4), basan bagrina (G.568/4); gelmeyince başuña (G.434/4); kakdılar başına (G.247/4); çıkupdur başdan (G.510/1); sarardup beñzini (G.277/3); düşdi bıçaga (G.483/4); çıkı cânumuz (G.204/1); geçüpdür cânuma (G.373/4); virme cânun (G.48/5), virürler cân (M.176); sıkıldı cânumuz (M.211); sıgmayı yazdı derisine (G.377/5); kesmez dilini (G.128/5); sunmış el (G.112/2), sunup el (G.339/4); düşmez elinden (G.536/3); gitdi elden (G.100/6); komaz elden (M.167/2); degmez eli (M.442/4); çekdüm elifler (G.67/1); çekmiş elifleri (G.88/3), çekdüm elif (G.205/2, M.241), çekdüm elifleri (G.222/3, G.431/3); kapdı elden (G.93/2); girse eline (G.65/3); olur engel (G.335/2); düşer gama (G.5/4); irdi göklere (G.74/5), irişdi göklere (G.294/2); getürme göñlü̃̃e (M.442/2); açılur göñlüm (G.468/1); kalur göñli (G.259/5); baglandı göñül (G.453/3); alup göñlümi (G.236/1); yıksa göñüuñi (G.369/1); 'aynuma gelmez (G.209/3); girdi gözine (G.278/2); işlenen günâhuñ (G.251/3); aldum haber (M.79/1); virdi harâret (G.536/3); varmasa hayrete (G.422/3); kesmege 'ırkın (G.99/3); kurıdupdur iligini (M.279/1); gelmezsin insâfa (G.201/3), gelmeyüp insâfa (G.263/4); yüritdi hâmeyi (G.408/5); agladı kan (G.408/1), aglayam kan (G.471/3); dökdi kan (G.110/5), döker kanı (G.496/1); boyandı kana (G.162/5), boyadum kana (G.471/5); yurlar kana (G.462/1); kurıdı kanı (G.271/3); içerler kanuñ (G.482/3), içdüñ kanın (G.557/3); açukdur kapusı (G.275/4); gelüp karşu 
(G.217/2), gelür karşu (M.373); çatma ebrûlaruñı (G.454/1); bilmezdi kendün (G.40/5); çeküp şemşîr (Muh.1/II, G.477/4); çek tîguñ (G.6/2), çekme tîg (G.74/4), çekdi tîgııı (G.441/1); tartılmış kılıcı (M.85/1); koyupdur kulagına (G.416/3, G.426/5, G.513/6); açmış kulagin (G.299/3); çekdi kulak (M.248/3); ider mat (G.68/7); çekdi mîl (G.373/2); tokındurdı nazar (M.144/2); dişlemiş barmak (M.246/1); kılduguma pî̧s-keş (M.151/2); virür reng (G.493/2); gösterdi rızâ (G.21/3); çekince sîneye (G.12/1, G.346/4); buldı şöhret (G.28/3); düşdi hâke (T.1/4), düşüpdür topraga (G.158/4); varur uyhuya (G.563/5); kalur üstinde (G.277/2); ditrer üstümde (G.328/3); yüridi üstine (M.347/2); atma yabana (G.256/4, G.305/2); yapışursın yakasına (G.428/1), yapışursın yakamuza (M.403); dökilse yaşum (G.323/4), döküp yaşum (G.412/4), dökse yaşın (G.426/1); çaldum yire (G.347/3); geçdi yirine (G.486/3); alışmaz kevkebi (G.523/5); düşdi yollara (G.491/4); oynadur yüregin (G.292/1), oynatdı yüregin (G.409/2); yanar yürek (G.208/3); burtardı yüzin (M.346/3); gösterür yüz (G.68/3); sürdüm yüzüm (G.89/2); urdı yüzini (G.433/5); karardı yüzi (G.271/2); sarardukça yüzüm (K.1/31), sarardursin yüzin (G.517/5); urur yüzine (G.61/5); irdi zevâle (G.186/3)."

Bir diğer devrik deyim yapısı üç ve daha fazla kelimeden oluşan deyimlerde yapılan öncelemelerdir: "Açık kaldı dehânı (G.547/3); agzına komışdur barmak (G.252/1), koyup agzına barmak (G.382/3), kodı barmak dehânına (M.392/1); eyledü̃ altun adın bakır (M.148); getürür arkañı yire (M.389/1); baş kodı ayagına (G.9/5), başını ayagına korsa (G.292/5), kodı baş ayagına (G.513/2); ayagına indi kara su (G.419/3); yire komazlar ayagim (M.454/2); aluruz ayag altına (G.31/3); kebâb itmiş idi bagrumı (G.403/6, G.417/5), bagrumı kıldı kebâb (G.555/3); taş basmadıysa bagrına (G.120/4); yumruk indürmez başından (G.259/1); kalmadı beñzinde kan (M.328/2); agzına geldi cânı (G.452/5); od düşüpdür cânına (G.507/2); duta el üstine (G.403/1); korın el gögsüme (G.388/4); kana sokardı elini (G.20/2); yüz sürer dâmânuma (G.445/5), yüzümi süre dâmenüñe (G.467/2); al ele göñlini (G.559/3), alup göñlin ele (M.262/3); kalsa açuk gözleri (G.445/4); kan boyarsa gözlerin (G.198/5); dökeyin gözüm yaşın (G.376/1); siler iken gözümüñ yaşını (G.349/4); dökildi içi yagı (G.535/2); barmak tıkadı kulagına (G.34/5); kulpı kalur destümde (G.419/4); itdüñ kül ufak (G.250/2); mâta olmışdur yakîn (G.371/5); ölüsi degmez imiş şivenine (M.381/2); bir pul bahâsı (G.281/1); akça mı sayduñ bahâsına (G.428/1, M.403); tâk oldı tâkatüm (G.203/2); hâk olayın yolında (G.88/2); geldi agzuma yüregüm 
(M.306/4); döker yüzi suyın (G.442/2), dökdüm yüz suyın (M.328/1); bakmaz old yüzüme (G.497/1)."

\section{I.6. Deyimi Oluşturan Kelimeler Arasına Kelime Girmesi}

Emrî Divanı'ndaki deyimlerde görülen bir başka özellik de deyimi oluşturan kelimeler arasına başka kelimelerin girmesidir. İki kelimeden oluşan bir deyimde kelimelerin arasına bir ya da birden çok kelime girebilmektedir: "Gider kişinüñ 'aklı (G.401/4); vire mi düzd-i sabâ aña emân (K.1/25); girme âhum ile sipihrüñ arasına (G.32/3); basdurma sâkî yâd ayak (M.248/1); kaldı hayf ayakda (G.98/3); geldi hep didükleri ben mübtelânuñ başına (G.435/1), geldi ey şîrîn-dehen Ferhâduñ âhir başına (M.383/1); getürdi bînîsin burnından (M.288/3); geçdi ey kaşı kemân cânumuza (G.381/1); yanar yok benüm içün cigerümden gayrı (G.537/1); düşürmez subha dek her şeb dilinden (M.471); tolaşur şehr şâiirlerinüñ dilleri (G.554/6); koma sâgarla sebû kulbını elden (G.534/5); alup göñlin ele (M.262/3); çek tîguñ ile sîneme ey serv-kad elif (G.6/2), elif kim kâmeti yâdına sînemde çekilmişdür (G.168/2); kalmaz hîç ayagumdan geri (M.315); düşse gam degül göbegüm (M.306/3); girdi gözine göñline anuñ (G.278/2); bagladum gîsû-y1 müşgînüñe âşüfte dili (G.467/2); virme gîsû-yı dil-âvîzine dil (G.295/1); çıkar sûzen gamın dilden (M.442/2); boyaduñ sen gözümüz (M.212); dikmiş çemende nergis göz (G.219/1); gönderem dimişdi size bir haber (G.193/4), gönderen dimiş birisiyle haber (M.196); virdi o çihreden gül-i pür-jâleye haber (G.76/2), virelden leb-i la'lüñ haberin (G.295/4), virdi kudûmı haberin (G.467/3), virdiler tugyân-1 eşkümden haber (M.395/1); oldum gam u endûh-1 miyânuñla hayâl (G.303/2); kaldı tîşe agzına barmak sokup hayrân (G.14/3); bitürdi gülsitân içre işin (G.165/5); tutar anuñ kanı (G.557/3); döküpdür anda kan (G.360/3); kanıkmış gussanuñ kanına (G.37/4); içdi surâhi çeşmüñ kanumı (G.499/4); kopar fitne çogaldıkda kıyâmet (G.61/2); kaldı bu hasret kıyâmete (G.509/1); girdi 'aceb koynuña (M.13); eylemişdi âteş-i mihrüñ yakup eczâmı kül (G.250/2); oldı Emrînüñ begüm eczâsı kül (G.571/7); oldı hep ma'lûm (M.307/1); ider dördinci evde mihri şeh mat (G.68/2); itmedi bülbül mâtem (M.381/2); almamışdur bâg-1 devrândan 
gül-i ra'nâ murâd (G.73/4); kesüp biri biri yanına na'1 (G.312/3), kesmiş ol ebrû-yı ham mâh-1 nevüñ cismine na'1 (M.243); bulupdur ser-nigûn zevrakla deryâdan necât (G.58/1), bulmaz âteşden necât (G.60/4); indi gicesi üstine nûr (G.111/2); ala kanumdan reng (G.290/2); virse agyâr-1 siyeh-rûya selâm (M.342/1); düşelden kaşlaruñ sevdâsına (M.236/1); kalkmışdı hat-1 sebz ile anuñ üstine (M.347/2); idüp hâmede yir (M.131/1); düşük imiş işlemedi sitâremüz (G.221/1); sarardı hep yüz (G.219/3); döndürür Emrînüñ ayva ile nârence yüzin (G.270/5); virür ey dil saña zahmet (G.62/4); irişdi aña zevâl (G.297/2); ola bir 'avratuñ zebûnı (G.548/3); çekse n'ola zencîre (G.124/5)."

Dikkat edilirse yukarıdaki deyimlerde hem deyimi oluşturan kelimelerin yer değiştirdiği hem de bu kelimelerin arasına kelime ya da kelimelerin girdiği görülür. Az da olsa bazı örneklerde deyimi oluşturan kelimelerin yeri değiştirilmeden sadece araya kelime ya da kelimelerin girdiği görülür: "Altında anuñ bu mübtelâ kalmaz (G.217/3); beñzümüñ hîn-1 helâkümde sarardug1 (G.290/2); cânuñı elbette vir (G.313/3), cânumı şemşîrüñe virdüm (G.421/5); cânı bir dil-rübâya 1smarla (G.506/1); göñlümden ey kaşı kemân tîrüñ geçer (G.98/4); ' aynına sen bir katrece gelmezsin (G.338/4); karşu şu kadar turdı (G.419/3); barmakla hilâli gösterür (G.546/2); üstüme yalıñ kılıçla geldi (G.375/2); yüzine bu sözleri her gâh dirin (M.335/1)."

Üç ve daha fazla kelimeden oluşan deyimlerde de deyimi oluşturan kelimelerin arasına kelime ya da kelimelerin girdiği görülmektedir: "Komazdı lâle agzına engüşt-i hayreti (G.422/3); kızıl çıkdı dirîgâ akçası (M.267/3); eyledüm bâzâr-1 '1şkuñda senün bagrum kebâb (G.46/4); taşı ko bârî basalum bagrumuza (G.557/4); baş üzre kıldı Mecnûn cây (G.483/3); hôş degül sihhatle başum (M.333/2); birine halk biñ katar (G.78/5); od düşer pervânenüñ cânına (G.123/4); oldı ciger pâre kebâb (G.152/4); turur çemende diken üzre (G.31/5); dökdi o merdüm ecel deri (G.515/2); egri oturur kendüsi ammâ sözi togru (G.421/4); elden komadum yâr etegin (G.385/1); dökdüm ruhı nakşında göz nûrın (M.238/2); görmez olupdur nergis-i bâguñ gözi (G.526/2); hâk ile eylerse 'aceb mi yeksân (K.1/13); uymaz ey gonca gül-i ra'nânuñ içi taşına (M.383/2); kanına 'âşıklaruñ la'lüñ getürdi çünki hat (Müs.1/V); kasd itdi la'lüñ kanuma (G.445/3); yirde komaz 
ehl-i 'ş̧kuñ kanını (M.479/1); tutma ey ser kendüñi yüksekde (M.255); su koysa dîde-i giryân ocagına (G.513/4); olursa bize öñ ayak (G.31/3); su gibi sâfî dilinde her zamân okur revân (K.2/18)."

Üç ve daha fazla kelimeden oluşan yukarıdaki örneklerde araya kelime girmesinin dışında deyimi oluşturan kelimelerin sırası da değişmiştir. Çok az olmakla birlikte bazı misallerde araya kelime girse de deyimi oluşturan kelimelerin sırası değişmez: "Beñzi eyvânuñ neden zerd oldugın (M.11/2); gözinüñ yaşlarını dür gibi dökdi (G.465/3); ocaguña dîde-i 'âşık su koyar (G.135/3)."

\section{I.7. Deyimlerde Değişiklik veya Deyimin Yerine Farklı Deyim Kullanımı}

Emrî Divanı'nda günümüzde kullanılan bazı deyimlerin farklı şekilde kullanıldığı da görülür. Şairin, bunların bir kısmında günümüzde aşağıda verilen şekliyle bilinen deyimin yerine o dönemde bilinen ve aynı anlama gelen benzer bir deyimi ya da deyimin benzer bir biçimini kullandığı söylenebilir. Ayrıca bazı deyimlerde yer alan kelimelerin eş anlamlısı ya da yakın anlamlısı ile yer değiştirdiği; şairin vezin, kafiye ve çeşitli söz sanatları için deyimleri kısaltma ya da deyimlerin kelimelerini farklı şekilde kullanarak deyimlerde bazı değişiklikler yapmakta bir mahsur görmediği de söylenmelidir. Buna göre şair "Adı sanı belirsiz" yerine "adı sanı yok" (G.183/3); "akıldan çıkmamak" yerine "akıl içinde mekân tutmak" (G.455/5); "aklı dağılmak" yerine "akl u fikri târumâr olmak" (Müs.I/I); "aklını başından almak" yerine "aklımı almak" (G.249/1, G.275/5, G.413/2, M.199, M.340/1); "altında kalmak" yerine "altından çıamamak" (G.277/2); "aradan çekilmek" yerine "aradan çıkmak" (G.506/1); "arkasımı dayamak" ya da "arka(sinı) vermek" yerine "arkası olmak" (G.128/3); "ayağına kara su inmek" yerine "ayağına su inmek" (G.237/2); "bahse girmek" yerine "bahse düşmek" (G.172/2); "başımı alıp gitmek" yerine "başını alıp kaçmak" (G.13/3); "bir ayă̆̆ çukurda olmak" yerine "ayă̆̆ çukurda" (G.263/4); "bire bin katmak" yerine "birine bin katmak" (G.78/5); "çalmadık kapı bırakmamak" yerine "çalmadık yer bırakmamak" (M.124/1); "dili durmamak" yerine "ağzı durmamak" (M.54/1); "dili tutulmak" yerine "ă̆zı tutulmak" (G.165/4); "dünyayı başına dar eylemek" yerine "dünyayı dar 
eylemek" (G.387/4); "eğri oturup doğru konuşmak" yerine "eğri oturur ama sözü doğru" (G.421/4); "eline geçmek" yerine "eline girmek" (G.65/3, G.289/5); "elini kana bulamak" yerine "elini kana sokmak" (G.20/2); "gizli din taşımak" yerine "gizli din tutmak" (G.527/1); "gözü açık gitmek" yerine "gözleri açık kalmak" (G.445/4); "gözünde olmamak" yerine "gözüne ('aynına) gelmemek" (G.209/3, G.338/4); "gözünün önüne gelmek" yerine "gözüne gelmek" (G.43/5); "gözünü kan bürümek" yerine "gözünü kan boyamak" (G.198/5); "içinin yă̆̆ erimek" yerine "içinin yă̆ı dökülmek" (G.535/2); "kafası kızmak" yerine "kellesi kızmak" (G.40/1); "kalem oynatmak" yerine "kalem yürütmek" (G.277/5, G.408/5); "kan ter içinde kalmak" veya "kan tere batmak" yerine "kan terlemek" (G.176/5, G.392/5, M.248/2); "kanına susamak" yerine "kanına kanıkmak" (G.37/4); "kendini bilmez" yerine "özünü bilmez" (G.77/5); "kılı kırk yarmak" yerine "kılı bin yarmak" (G.302/5); "pabucu dama atılmak" yerine "başmăğ (ayakkabısı) dama atılmak" (G.212/3); "pişmiş aşa soğuk su katmak" yerine "pişmiş aşı bozmak" (G.278/4); "parmağı ă̆zında kalmak" yerine "ă̆zına parmak sokmak/komak" (G.14/3, G.252/1, G.382/3, G.422/3, M.392/1); "peşkeş çekmek" yerine "peşkeş kılmak" (M.151/2); "sırtını yere getirmek" yerine "arkasın yere getirmek" (M.389/1); "üstüne titremek" yerine "üstünde titremek" (G.328/3); "yere göğe koymamak" yerine "ayağını yere koymamak" (M.454/2); "yedi kat yerin dibine geçmek" yerine "yedi kat yere geçmek" (G.304/2); "yüz yüze gelmek" yerine "yüze yüz gelmek" (G.172/3) veya "yüze yüz olmak" (M.172/1) deyimini kullanmıştır.

\section{I.8. Yardımcı Fiil Kullanılan Deyimler}

Yardımcı fiille kurulan deyimlerde şair, "etmek, eylemek, kılmak, olmak" yardımcı fiillerini kullanırken aşağıdaki örneklerde de görüleceği gibi "bağrı kebap etmek/eylemek/kılmak, bağrını kan (hûn) etmek/eylemek, çâk-i girîbân etmek/eylemek, eksik etmemek/eylememek, el uzunluğu etmek/eylemek, fark edilmek/olunmak, göz etmek/eylemek, hâk etmek/eylemek/kılmak" vb. deyimlerde aynı deyimde zaman zaman yardımcı fiilli değiştirmiştir. Yardımcı fiil kullanılan deyimler şunlardır: Altın adım bakır eylemek (M.148); ayıp etmek (M.231/2); aklı terk etmek (G.347/6); bağrı kebap etmek (G.403/6, G.417/5); 
bağrı kebap eylemek (G.46/4); bağrı kebap kılmak (G.555/3); bağrını kan (hûn) etmek (G.407/1); bă̆rımı kan (hûn) eylemek (Müs.I/III); başı hoş olmak (G.498/4); başı hoş olmamak (M.333/2); bir olmak (G.270/1); borç eylemek (G.551/5); ciğer kebap olmak (G.152/4), çâk-i girîbân etmek (G.540/1, G.561/4); çâk-i girîbân eylemek (G.318/2, G.450/4); girîbânımı çâk kılsa (G.462/3); dünyayı (başına) dar eylemek (G.387/4); eksik etmemek (M.313/2); eksik eylememek (M.116/2); eksik olmamak (G.91/4, G.170/2); el uzunluğu etmek (G.295/3); el uzunluğu eylemek (G.10/4); engel olmak (G.335/2); ezber eylemek (K.2/18); fark etmek (G.378/2, G.394/2, M.484); fark olunmak (G.328/2, G.473/4); göz etmek (G.41/2); göz eylemek (G.304/1, M.14/1, M.421/1); göz kulak olmak (G.439/3); gubâr olmak (G.30/1); hâk etmek (G.403/1); hâk eylemek (G.58/2, G.130/2); hâk kılmak (G.518/3); hâk olmak (G.438/5, G.459/5, M.107/2, M.255/1, M.422); hâk ile yeksan eylemek K.1/13); hâke yeksan eylemek (G.376/4); haram olmak (M.350); hayal olmak (G.303/2); ikrar eylemek (G.502/4); kanına kast etmek (G.445/3); kanını helal etmek (G.477/4); kanlı bıçaklı olmak (G.476/5); kılıç bıçak olmak (G.439/1); kul etmek (G.554/1); kul olmak (G.14/1); kulaktan âşık etmek (G.123/5, M.461/1); kulaktan âşık olmak (G.479/4); kül etmek (M.218/4, M.277/1); kül eylemek (G.250/2, G.298/2); kül olmak (G.139/4, G.571/7); kül ufak etmek (G.250/2); malum olmak (G.479/3, G.546/4, M.307/1); mat etmek (G.68/2, G.68/7); mata yakın olmak (G.371/5); matem etmek (M.381/2); minnet etmek (G.73/1); önayak olmak (G.31/3); pazar(llk) etmek (G.244/3, G.501/3, M.177/1, M.184/1); peşkeş kılmak (M.151/2); reng eylemek (G.27/5); serkeşlik etmek (G.289/4); tâkati tâk olmak (G.203/2); toprak olmak (M.362/3); yer etmek (G.100/5, G.423/2, M.131/1, M.244/2, M.289/4); yol etmek (M.158/4); yolunda paymal olmak (G.288/1); yolunda hâk olmak (G.88/2, M.422); yüz karalığı etmek (G.177/5); yüze yüz olmak (M.172/1); zebunu olmak (G.548/3); zindan olmak (G.209/1).

\section{I.9. Deyimlerde Arapça ve Farsça Kelimeler}

Emrî, deyimlerde genellikle Türkçe kelimeleri tercih etmekle birlikte bazı deyimlerde vezin, kafiye ve çeşitli söz sanatları zaruretiyle Türkçe kelimelerin eş anlamlısı olan Farsça ve Arapça kelimeleri de kullanmıştır: "Acı sühan (G.401/1); dehânı açık kalmak (G.392/1, G.547/3); 
dehân açmamak (G.474/3); ă̆zına engüşt komak (G.422/3), dehânına parmak komak (M.392/1); aklı târumâr olmak (Müs.I/I); Hudâ'ya ısmarlamak (G.506/1); kadem çekmek (G.346/5); cüdâ düşmek (G.50/1, G.240/3, G.266/2, G.406/1); bağrı hûn olmak (G.118/1); bağrını hûn etmek/eylemek (Müs.I/III, G.407/1); benzi zerd olmak (M.11/2); baş üstünde cây kllmak (G.483/3); bir katre (G.43/2, G.80/1, G.320/1, G.323/3, G.324/4, G.338/4, G.484/5, M.18/2, M.69, M.71); bir pâre (G.59/3, G.281/5, G.469/5); dâmanına yüz sürmek (G.445/5, G.467/2); dil bağlamak (G.104/2, G.467/2); dil vermek (Tah.1/II, G.110/4, G.295/1, G.417/4); dilden çıkarmak (G.131/5, M.442/2); dilden geçirmek (G.545/1); çeşm-i bed değmek (G.467/1), nazar değmek (G.564/5); nazardan düşmek (M.478/3); 'aynına gelmemek (G.209/2, G.209/3, G.338/4); iğne yutmuş kelbe dönmek (G.48/3, M.20); hâme yürütmek (G.408/5); kanlar kay' etmek (G.58/3); baht-ı siyâh (G.558/2); ebrû çatmak (G.454/1); tîg çekmek (G.6/2, G.74/4, G.441/1, M.225); şemşir çekmek (Muh.1/II, G.477/4); tîgden geçmek (G.327/4); gûşuna koymak (G.173/4); kulpu destinde kalmak (G.419/4); ölüsü şîvenine değmemek (M.381/2); penbe atmak (G.539/5); seng-dil (G.558/3); hâke düşmek (T.1/4); hâk etmek/eylemek/kılmak (G.58/2, G.130/2, G.403/1, G.518/3); gubâr olmak (G.30/1), hâk olmak (G.438/5, G.459/5, M.107/2, M.255/1, M.422); çâk-i girîbân etmek/eylemek (G.215/5, G.318/2, G.450/4, G.462/3, G.540/1); hâk ile yeksân eylemek (K.1/13), hâke yeksân eylemek (G.376/4); kevkebi alışmamak (G.523/5); sitâresi düşük (G.221/1); yolunda hâk olmak (G.88/2, M.422); ruhsâr sürmek (M.205); rûyu sararmak (G.12/3), ruhsâr-ı zerd (G.12/6)."

Divan'da dikkati çeken bir özellik de deyimler bakımından oldukça zengin olmasına rağmen atasözlerinin aynı yoğunlukta yer almayışıdır. Deyimlerle kıyaslandığında Emrî, atasözlerini fazla kullanmamıştır.

\section{I.10. Yöntem}

Emrî Divanı'nda kullanılan deyimler, eserin baştan sona dikkatli bir şekilde taranmasıyla tespit edilmiştir. Buna göre Divan'da 541 farklı deyim toplam 1031 defa kullanılmıştır. Ancak yine de dikkatimizden kaçan deyimlerin bulunması muhtemeldir. Aşağıda deyimler harf sırasına göre verilirken önce deyim yazılmış, hemen ardından deyimin geç- 
tiği yerler belirtilmiş, sonra deyimin anlamı ortaya konmuş ve deyim ve anlamı ile ilgili başvurulan kaynaklar verilmiştir. Verilen örneklerde M. A. Yekta Saraç'ın metni esas alınmış, metnin okunuş ve imlasına müdahale edilmemiştir. Makale sınırlarını aşacağı için deyimlerin çoğuna örnek verilmemiş; divan şiirine özgü, günümüzde az kullanılan, daha az bilinen bazı deyimlere birer beyit ya da bent örnek olarak verilebilmiştir. Deyimin geçtiği yerler şiir ve beyit/bent numarası verilerek (K.1/18, G.245/3, M.287/1 gibi) belirtilmiştir. Referans şiirlerde "K.: Kaside, Mur.: Murabba, Muh.: Muhammes, Müs.: Müsemmen, Tah.: Tahmis, Müst.: Müstezad, G.: Gazel, M.: Mukatta', T.: Tarih" şeklinde kısaltmalar kullanılmıştır. Deyimin anlamı ortaya konulurken yukarıda da belirtildiği gibi deyim sözlükleri kaynak olarak kullanılmış, verilen anlamın sonunda ilgili deyim ve anlamı hangi kaynaklarda yer alıyorsa sayfa içi dipnotla belirtilmiş, bu dipnotlarda yazarların soyadları harf sırasına göre verilmiştir. E. Kemal Eyüboğlu'nun sözlüğünde deyim anlamları verilmediğinden bu kaynaktan yalnızca deyimin yer alıp almadığına bakılmıştır. Sayfa içi dipnotlarda deyim sözlükleri kaynak olarak gösterilirken yazarın ad ve soyadının baş harfiyle kısaltma yapılmış, basım tarihi gereksiz bir tekrar oluşturacağı için yazılmamıştır. Buna göre “ÖAA: Ömer Asım Aksoy 1984, EKE: E. Kemal Eyüboğlu 1973, İP: İsmail Parlatır 2008, AP: Ali Püsküllüoğlu 2006, MES: M. Ertuğrul Saraçbaşı 2010, MAT: M. Ali Tanyeri 1999" şeklinde kısaltmalar kullanılmıştır. Deyim sözlüklerinde yer almayan deyimlerin anlamları, şairin kullanımından yola çıkılarak ortaya konmuştur. Deyimlerle ilgili çalışmalarda yer almasını önemsediğimiz, verilen örneklerin nesir şeklinde günümüz Türkçesine aktarılması, yine makale sınırlarını hayli aşacağı için verilememiştir. 


\section{EMRÎ DİVANI'NDAKİ DEYİMLER}

Emrî Divanı'nda tespit edebildiğimiz deyimler şunlardır:

Acı dil vermek: Acı söz söylemek (MAT: 9).

Acı diller virüben Emrîye cân virsün dimiş

Hey ne şîrîn söylemiş la'l-i şeker-güftârın öp (G.57/5)

Ac1 söz (G.42/3, G.66/3, G.401/1): Söyleneni üzecek, dokunaklı söz; sert, kırıcı, ağır söz; (AP: 14; MES: I/18; MAT: 9).

Âdet edinmek (G.399/4): Bir şeyi yapmayı huy ve alışkanlık hâline getirmek (IP: II/31; AP: 21; MES: I/29).

Ad1 sanı belirsiz (yok) (G.183/3): Ne olduğunu, nerede olduğunu bilen yok; kimin nesi olduğu bilinmeyen (ÖAA: II/532; EKE: II/4; IP: II/28; AP: 25; MES: I/31).

Adım atmamak (G.520/3): Bir yere kesinlikle gitmemek; birini, bir yeri aramamak; o yerden dışarı hiç çıkmamak (ÖAA: II/531; IP: II/31; AP: 23; MES: I/32).

Ağır ol (G.133/3): Soğukkanlılı̆̆ını yitirme, sabırlı davran, ağırbaşlılığı elden bırakma; hiç acele etme (EKE: II/5; IP: II/35; AP: 29; MES: I/40).

Ağız açmak (G.128/4, G.524/2, M.8, M.294): Konuşmaya başlamak, söz söylemek; azarlamak, paylamak (EKE: II/5; İP: II/36; MES: $\mathrm{I} / 42)$.

Ağız (dehân) açmamak (G.256/2, G.474/3): Söylemesi beklendiği halde hiçbir şey söylememek (ÖAA: II/535; IIP: II/36; AP: 29; MES: I/42; MAT: 13).

Ağız eğmek: Yalvarırcasına bir şey istemek, yalvar yakar olmak (ÖAA: II/536; IP: II/37; AP: 31; MES: I/43; MAT: 14).

Ey güneş mâh-ı neve gösterme ebrûñ gelür Karşuña agzin eger bir agzı egridür hilâl (M.289/2) 
Ağzı (dehânı) açık kalmak (G.392/1, G.525/1, G.547/3, M.422): Hayretten şaşmak, şaşırıp kalmak (ÖAA: II/539; EKE: II/7; İP: II/39; AP: 33; MES: I/46; MAT: 14).

Goncaya esrâr-ı la'lüñden kokulatmış nesîm Agzı açuk kaldugın 'ayb itme kan hayrân imiş (M.231/2)

Ağzı/dili durmamak (M.54/1): Sürekli konuşarak gevezelik etmek; söylenmemesi gereken şeyleri de söylemek (EKE: II/138; IP: II/297; AP: 281; MES: I/364).

Ağzı/dili tutulmak (G.165/4): Aşırı korku, sevinç şaşkınlık gibi durumlarda söz söyleyemez olmak (ÖAA: II/722; EKE: II/138; İP: II/300; AP: 283; MES: I/364; MAT: 88).

Ağzı var dili yok (G.395/5): Pek sessiz, çok az konuşur, kimseye karşıllık vermez, kendi hâlinde; derdini anlatamayan (ÖAA: II/546; EKE: II/9; IP: II/48; AP: 34; MES: I/48; MAT: 19).

Ağzına almak (G.35/5, G.59/4, G.268/3): Adından söz etmek, söylemek (EKE: II/7; IP: II/41; MES: I/46).

Ağzına almamak (M.346/1): Söz konusu etmemek, anmamak (EKE: II/9; IIP: II/41; MES: I/49; MAT: 14).

Ağzına parmak koymak/sokmak (G.14/3, G.252/1, G.422/3, M.392/1): Pek çok şaşmak, şaşkınlıktan bakakalmak; hayretler içinde kalmak (ÖAA: II/1006; EKE: II/356; IPP: II/709; AP: 656; MES: II/957; MAT: 209).

Geldi nây-ı nâleme bezmüñde âheng itmege

Hayrete vardı koyup agzına barmak nây-zen (G.382/3)

Ağzına söğmek (G.384/3): A ğzının payını vermek, hakaret etmek (EKE: II/10; İP: II/46-47, 349, 353; MES: I/56).

Söverem didi kim diler dilber

Agzuma sögmege behâne arar (G.202/4)

Ağzını tutmak (G.524/2, M.224/2): Yerli yersiz konuşmamak, sır saklamak; kötü söz söylemekten kaçınmak; bir konuda istenmeyen düşüncelerin açığa çıkmasını bir şekilde önlemek (ÖAA: II/546; EKE: II/12; IP: II/48; AP: 43; MES: I/55; MAT: 17). 
Ağzının payını vermek: bk. Ağzına söğmek.

Ağzının suyu akmak: Çok beğenmek, elde etmeyi istemek, aşırı imrenmek (ÖAA: II/545; EKE: II/12; İP: II/47; AP: 42; MES: I/56; MAT: 17).

Dökilen jâle degül la'l-i lebüñ vasfin ider

Agzı suyın akıdur goncalaruñ bâd-ı sabâ (G.19/2)

Akçası kızıl çıkmak: Değersiz bulunmak; beklendiği kadar değer görmemek.

Metâ' $\imath$ mihrüñe ey mâh nakd-i eşki satmışdum

Kızıl çıkdı dirîgâ akçası hep çeşm-i pür-hûnuñ (M.267/3)

Akıl içinde mekân tutmak: Unutmamak, akılda tutmak; sürekli hatırlanmak (EKE: II/15; IP: II/53; AP: 47; MES: I/64).

'Aklum içinde mekân tutdı hayâli kaşuñun

Emriyâ râ gibi kim yazıla idrâk içre (G.455/5)

Akıldan çıkmamak/gitmemek: bk. Akıl içinde mekân tutmak.

Aklı başından gitmek (M.268/2): Bilincini yitirmek, bayılmak; hayretten, sevinçten veya korkudan ne yapacağını bilememek (ÖAA: II/552; EKE: II/16; İP: II/57; AP: 51; MES: I/67; MAT: 21).

Aklı dağılmak: bk. Aklı fikri târumâr olmak.

Aklı fikri târumâr olmak (Müs.I/I): Kafası karışık olmak, düşünceyi belli bir konu, sorun üzerinde toparlayamamak (EKE: II/16; IP: II/57; AP: 51; MES: I/68).

Aklı gitmek (G.386/2, G.401/4, G.445/2, G.519/4): Hayretten şaşırmak, korkmak; hayran olmak, çok beğenmek; bilincini yitirmek (ÖAA: II/553; EKE: II/17; IP: II/58; AP: 52; MES: I/68).

Aklı komak: Aklıyla hareket etmemek. Ayrıca bk. Aklı terk etmek.

'Aklı kodum cünûn yolın tutdum

Yol bilen kârbâna katlanmaz (G.220/2)

Aklı terk etmek: Aklıyla hareket etmemek, kendinden geçmek. Ayrıca bk. Aklı komak, Aklından geçmek. 
'Akl u sabrı terk idüp dîvâne olsam tañ mıdur

Leylî-i zülfine anuñçün giriftâr olmışam (G.347/6)

Aklından geçmek: Aklıyla hareket etmemek, kendinden geçmek, sarhoş olmak (EKE: II/17). Ayrıca bk. Aklı komak, Aklı terk etmek.

'Arak görse lebinde 'akl u cânından geçer Emrî

Ziyâde mest olur âdem 'arak-âmîz olan mülden (G.393/5)

Aklını aldırmak (M.456/2): Deli gibi olmak, aklını kaybetmek (MES: I/73).

Aklını (başından) almak (G.249/1, G.275/5, G.413/2, M.199, M.340/1): Hayrette birakmak, çok şaşırtmak; çekiciliği ve güzelliğiyle büyülemek; aklını başından almak (ÖAA: II/555; EKE: II/18; IP: II/61; AP: 55; MES: I/73; MAT: 20).

Allah'a (Huda'ya) 1smarlamak (G.506/1): Bir işi veya kimseyi Allah'a havale etmek, Allah'a emanet etmek (EKE: II/24; MES: I/97).

Altın adını bakır eylemek: Kötü işler yaparak temiz ve parlak ününü karartmak, eski iyi adını uygunsuz davranışlarıyla kötüye çevirmek (ÖAA: II/568; EKE: II/25; İ: II/85; AP: 76; MES: I/103; MAT: 24).

Nihânî içdügüñ kıldı yüzüñde tâb-ı mül zâhir

Be sôfî rûy-ı zerdü̃ eyledü̃ altun adın bakır (M.148)

Altında kalmak: bk. Altından çıkamamak.

Altında kalmamak (G.217/3): Karşılığını vermek, gördüğü iyilik veya kötülüğü karşılıksız birakmamak (ÖAA: II/568; İP: II/83; AP: 77; MES: I/104; MAT: 25).

Altından çıkamamak: Ezilmek, ezilip büzülmek, mahcup olmak; karşılık verememek (IIP: II/83; AP: 76; MES: I/104).

Çıkarma yüksege âhum degüldür bir metâ' ey çarh

Kalur üstinde altından çıkamazsın sakın anuñ (G.277/2) 
Aman vermemek: Huzursuz etmek, göz açtırmamak; acımayıp öldürmek, canını almak (ÖAA: II/571; EKE: II/26; İP: II/88; AP: 80; MES: I/107; MAT: 25).

Zer-nişân hançerini aldı elinden bîdün

Sokmayınca vire mi düzd-i sabâ aña emân (K.1/25)

Aradan çıkmak/çekilmek (G.506/1): Aradan çekilmek, uzaklaşmak; ilişiğini kesmek; herhangi bir iş yapılırken işi başkalarına bırakmak (EKE: II/28; IP: II/97; AP: 90; MES: I/118; MAT: 26).

Araya girmek (G.32/3, Tah.2/III): Aralarında anlaşmazlık bulunan iki kişiyi uzlaştırmaya çalışmak; iki kişinin arasındaki bir işe karışmak; bir iş yapılmaktayken ona engel olacak başka bir şey çıkmak (ÖAA: II/579; EKE: II/29; İP: II/98; AP: 93; MES: I/120; MAT: 27).

Arkası olmak (G.128/3): Birinin himayesine girmek, koruyuculuğuna güvenmek, ondan güç almak (ÖAA: II/583; EKE: II/30; İP: II/104; AP: 100; MES: I/125; MAT: 28). Ayrıca bk. Arka(sını) vermek.

Arkasını dayamak: bk. Arkası olmak.

Arkasını sığamak/sıva(zla)mak: Beğendiğini okşayarak göstermek; birini övmek; iltifat etmek (ÖAA: II/583; EKE: II/125; İP: II/104; AP: 100).

'Uşşâkı n'ola çigner ise atı her zamân

Ol şeh-süvâr-ı hüsn anuñ arkasın sıgar (G.78/2)

Arka(sını) vermek (G.546/3, M.29/2): Birinin himayesine girmek, koruyuculuğuna güvenmek, ondan güç almak; bir şeye yaslanmak (ÖAA: II/583; EKE: II/30; IP: II/104; AP: 100-101; MES: I/126; MAT: 28). Ayrıca bk. Arkası olmak.

Arkasını/sırtını yere getirmek (M.389/1): Güreşte rakibini sırtüstü yere yatırarak yenmek; üstün gelmek; alt etmek (EKE: II/30; İP: II/767; AP: 100; MES: II/1028).

Aşka düşmek (G.147/5): Sevdalanmak, âşık olmak, tutulmak (EKE: II/32; IP: II/112; AP: 106; MES: I/132). 
Ayağa düşmek (G.483/2): Acz içinde kalmak, kuvvetten düşmek, kıymetini kaybetmek, hakir olmak; sıradanlaştırmak; bir işe ilgisiz ve yetkisiz kimseler karışmak (EKE: II/35; IP: II/122; MES: I/141; MAT: 30).

Ayağı çukurda (olmak) (G.263/4): Yaşayacak çok az zamanı kalmış olmak, çok yaşlanmış olmak (ÖAA: II/642; EKE: II/79; IP: II/186; AP: 175; MES: I/216).

Ayağına baş koymak (G.292/5, G.513/2): Ayağına kapanmak, yalvarmak (EKE: II/36; MAT: 33).

Kûy-ı yâra vardugıyçün baş kodı ayagına

Sanma derd ü mihnet itdi kaddin Emrîü̈ñ dü-tâ (G.9/5)

Ayağına düşmek (G.327/3, G.385/1, G.525/3, M.28/1, M.284/2, M.331/1): Yalvar yakar olmak; ayağına kapanmak (EKE: II/37; IP: II/124; AP: 116; MES: I/143; MAT: 34).

Ayagına düşđügüm görmiş nifâk itmiş rakîb

Dôst incinmiş baña şerrin görü̈̃ ol düşmenüñ (M.265/2)

Ayağına gelmek (G.216/3): Bir kimse ya da şey, kendisinin yanına gelmek; alçakgönüllülük göstererek birinin yanına gitmek; kısmetine çıkmak; beklenmedik bir nimete ermek (ÖAA: II/596; EKE: II/38; IP: II/124; AP: 116; MAT: 31).

Ayağına kara su inmek (G.237/2): Çok dolaşmaktan, birini arayıp sormaktan, yol yürümekten veya uzun süre ayakta beklemekten dolayı çok yorulmak (ÖAA: II/597; EKE: II/38; IIP: II/129; AP: 117; MES: I/143; MAT: 36).

Hâl-i ruhsâruña karşu şu kadar turdı ezel

Merdüm-i dîdemüñ ayagına indi kara su (G.419/3)

Ayağını almak (M.257): Aleyhte bulunarak kuvvet ve itibardan düşmek; çelme takıp yere sermek (MAT: 36).

Ayagin almaga kasd itdi çünkim sâkiyâ yârân

Tutılur duhter-i rezle safâ bezminde peymâne (G.510/4) 
Ayağını (kadem) çekmek: Sürekli gittiği bir yere artık gitmez olmak; ilgiyi kesmek (ÖAA: II/597; EKE: II/38-39; IP: II/125; AP: 118; MES: I/144; MAT: 32).

Çü bildüm bu fenâ mülküñ bekâsı yok bir el öñdin Ayak ayak fenâ iklîmine Emrî kadem çekdüm (G.346/5)

Ayağını kesmek: Bir yere artık pek gitmez olmak; başkasını bir yere artık uğramaz duruma getirmek, gitmesini ve uğramasını engellemek (ÖAA: II/598; EKE: II/39; IP: II/125; AP: 118; MES: I/144; MAT: 32).

Gözüm evinden ayagını kesdi leşker-i hâb

Kılıcın anda asaldan hayâl-i müjgânuñ (G.285/2)

Ayağını pek basmak: Ayağını sağlam basmak, bir konuda kararlı olmak, diretmek (EKE: II/39).

Cânumı bûseye bâzâr ideyin sun elüñi

Yiter ey Yûsuf-ı gül-çihre ayaguñ pek bas (G.244/3)

Ayağını yere koymamak: Nasıl ağırlayacağını, nasıl memnun edeceğini bilmemek, çok değer vermek (EKE: II/426; İP: II/914; AP: 806; MES: II/1208).

Meyl ideli şarâba lebüñ buldı i'tibâr

Bezm-i safâda yire komazlar ayagını (M.454/2)

Ayağının altına almak (G.31/3): Birini yere yatırıp tekme ile dövmek; yararlanabileceği şeyi hor görüp tepmek (ÖAA: II/598; EKE: II/39; IP: II/126; AP: 118; MES: I/145).

Ayağının tozu (türâbı) olmak: Bir başkasına kul köle olmak, onun her emrini yerine getirmek (ÖAA: II/599; EKE: II/39; İP: II/127; MES: I/146).

Nâfe hâk-i kademin başda götürürken anuñ

Zülf-i yâra dir ayaguñ tozıyın hatt-ı gubâr (G.129/3)

Ayağının tozuyla (G.396/2): Uzak bir yerden veya yoldan gelir gelmez, henüz dinlenmeden ve yerleşmeden (ÖAA: II/598; EKE: II/39; IP: II/126; MES: I/146; MAT: 33). 
Ayak bastırmamak (M.248/1): Gelmesine izin vermemek, bir yere girmesini engellemek (EKE: II/40).

Ayak dolamak/dolaştırmak: Yürümekte olan bir işe engel çıkarmak, bir kimseyi kötü duruma düşürecek söz veya davranışta bulunmak (ÖAA: II/601; MAT: 36).

Tolu iç dirse eger bezmde agyâr saña

İçeyin dime sen ayak tolar ey yâr saña (M.3)

Ayak götürmek: Koşmak; çekilip gitmek, ayağını çekmek (EKE: II/40-41; MAT: 37).

Götürdüm ayagı devr-i zemâne bezminden

Tarîka girdüm eyâ şeyh himmet eyle baña (M.7/2)

Ayak teri (G.550/1): Gelip iş yapan kimseye verilen ücret, hizmet ücreti (EKE: II/41; MAT: 36).

Rindlerden nakd-i cân ayak teri alur müdâm

Şevk bâzârında sâkî kim ayak dellâlıdur (M.83/2)

Ayakta kalmak (G.98/3): Oturacak yer bulamamak; oturulacak yer olduğu halde ayakta beklemek; işleri kötü gitmesine rağmen yıkılmamak; işi ilerletemeyip yarıda bırakmak (ÖAA: II/602; IP: II/130; AP: 122; MES: I/149; MAT: 37).

Ayrı (cüdâ) düşmek (G.50/1, G.240/3, G.266/2, G.406/1): Birbirinden uzakta kalmak, ayrı ayrı yerlerde olmak; düşünce ve davranışça uyuşmamak (EKE: II/42; IP: II/134; AP: 129; MES: I/154).

Bağrı kan (hûn) olmak: Çok dert ve acı çekmek (EKE: II/45).

Çarh-ı ser-keş dest-i âhumdan zebûn olmış-durur Kâmeti iki bükilmiş bagrı hûn olmış-durur (G.118/1)

Bağrı katı (G.542/2): Duygusuz, acımasız, katı yürekli (ÖAA: II/915; EKE: II/391; IP: II/821; AP: 738; MES: I/163). Ayrica bk. Taş bağırlı, Taş yürekli/kalpli.

Bağrı kebap etmek/eylemek/kılmak (G.46/4, G.403/6, G.417/5): Çok acı çekmek, derinden üzüntü duymak, bağrı yanmak (EKE: II/45). 
Âteş-i gurbet egerçi bagrumı kıldı kebâb

Câm-ı la'lînden şarâb-ı hôss-güvâr egler beni (G.555/3)

Bağrı yanık/yanık bağırı (G.3/4, M.81): Çok dert, acı çekmiş, sıkıntılı günler yaşamış (kimse) (ÖAA: II/611; EKE: II/45; IP: II/140; AP: 135; MES: I/163; MAT: 40).

Bağrına basmak (G.10/5, G.87/4, G.279/1, G.335/1, G.494/2, G.557/4, G.568/4, M.127): Kucağına almak, kollarıyla sıkıca sarmak; birini sevgi ve şefkatle yanına alıp korumak, yetiştirmek (ÖAA: II/611; EKE: II/46; IP: II/140; AP: 135; MES: I/164; MAT: 40).

Bağrına taş basmak (G.120/4, G.557/4): Hiçbir tepki göstermeden her türlü sıkıntıya, acıya ve zorluğa katlanmak; acısını içine gömmek (ÖAA: II/611; EKE: II/46; İP: II/140; AP: 135; MES: I/164; MAT: 40).

Bağnını delmek (G.151/4, G.262/4, G.356/1): Acısı içine işlemek, derinden yaralamak (ÖAA: II/611; EKE: II/47; IP: II/140; AP: 135; MES: I/164; MAT: 55).

Bağnını kan (hun) etmek/eylemek (Müs.I/III): Çok acı çektirmek (EKE: II/48).

Şol dem ki gamuñ bagrumı hû̃ itdi sitemden

Gözüm yaşı hûn-âbe olup akar o demden (G.407/1)

Bahis tutuşmak/Bahse girmek: bk. Bahse düşmek.

Bahse düşmek: Herhangi bir konudaki görüşünde veya iddiasında haklı çıkmak için iddiaya girişmek; bir yarış çerçevesinde sözlü anlaşma yapmak (ÖAA: II/611; İP: II/141; AP: 135; MES: I/164165; MAT: 40).

Meger câdû gözüñ sâhir saçuñla bahse düşmişler

Ki biri sihr ile tîr itse mûyı biri mâr eyler (G.172/2)

Baş çatmak: Bir araya gelmek, baş başa vermek (EKE: II/52; MAT: $54)$.

Kemân-ebrûlaruñ kim baş çatup kâmet dü-tâ itmiş

San iki hasmdur yeñmiş biri birini yâ itmiş (G.228/1) 
Baş çekmek (G.356/5): Baş kaldırmak, buyruk dinlememek, isyan etmek; öncülük etmek, ilk adımı atmak; halayın başında oyunu yönetmek (ÖAA: II/617; EKE: II/52; İP: II/151; AP: 144; MES: I/174; MAT: 59). Ayrıca bk. Serkeşlik etmek.

Baş indirmek: İtaat etmek, söz dinlemek (EKE: II/54; MES: I/174; MAT: 55).

Sihrde basmış-durur hôd anı müşgîn kaşlaruñ

Pes niçün baş indürür yâ çeşmüñüũ câẑ̂sına (G.436/3)

Baş koymak (G.425/3): Bir amaca varmak için ölümü göze almak, bir uğurda kendini adamak (ÖAA: II/627; EKE: II/55; IP: II/163; AP: 156; MES: I/175; MAT: 49).

Baş üstünde tutmak: bk. Baş üstünde yer vermek.

Baş üstünde yer vermek (yeri var): Saygılı davranmak, çok iyi ağırlamak, el üstünde tutmak, değer vermek (ÖAA: II/629; EKE: II/56; IP: II/164; AP: 157; MES: I/176; MAT: 51).

Şebîh oldugıçün Leylî saçına

Baş üzre kıldı Mecnûn cây zâga (G.483/3)

Baş vermek (M.113/2): Buğday, arpa gibi bitkiler büyüyüp başakları belirmek; (çıban) olgunlaşmak (ÖAA: II/629; EKE: II/57; İP: II/165; AP: 157; MES: I/176).

Başa çıkarmak (G.50/5, G.537/5): Bir işi başarıyla sonuçlandırmak; çok yüz vermek, şımartmak (ÖAA: II/615; EKE: II/57; IPP: II/148; AP: 142; MES: I/176).

Başı devletli: Uğurlu, talihli, bahtı açık kimse.

Başı devletlü kuldur ol ki şâhâ Ayaguña ide zîr ü zeber ruh (G.68/5)

Başı hoş olmak: İyi geçinmek, uyumlu olmak; bir şeyden hoşlanmak (ÖAA: II/619; EKE: II/60; IP: II/153; AP: 147; MES: I/179).

'Işk esrârm yiyen la'lüñe meyl itse n'ola

Çünki başı hôş olur hayrânlaruñ tatlu ile (G.498/4) 
Başı hoş olmamak: İyi geçinememek, uyumlu olmamak; bir şeyden hoşlanmamak (ÖAA: II/619; EKE: II/60; İP: II/153; AP: 147; MES: I/179).

Hôş degül sihhatle başum derde ögretdi mizâc

Saghlk ile zindegânî idemem derd isterin (M.333/2)

Başına bela(yı satın) almak (G.4/5): Sıkıntı ve üzüntü verici olduğu sonradan anlaşılan bir işe kendi isteği ile girişmiş olmak; durup dururken belalı bir işe kalkışmak (ÖAA: II/620; EKE: II/61; İP: II/154; AP: 147; MES: I/182).

Başına bela gelmek (G.468/2): Sıkıntı ve üzüntü verici bir işle karşılaşmak.

Baş(1n)a gelmek (G.434/4, G.435/1, G.494/3, M.383/1): İstenmeyen, üzücü bir olay veya durumla karşılaşmak; kötü bir duruma uğramak (ÖAA: II/616; EKE: II/62; İP: II/156; AP: 149; MES: I/184; MAT: 44).

Başına gün doğmak (G.382/1): Talihi yâr olmak, işi hep yolunda gitmek (EKE: II/62-63; MAT: 53).

Bekle kûyını ola kim çıka yâruñ göresin

Başuña gün toga ey dil der-i dil-dâruñda (G.452/3)

Başına kakmak (G.247/4): Yapılan bir iyiliği sürekli olarak söyleyerek biktırmak (ÖAA: II/616; EKE: II/63; İP: II/156; AP: 149; MES: I/185; MAT: 48).

Başına üşmek/üşüşmek (G.122/2): Çabucak etrafına toplanmak (EKE: II/64; MES: I/185).

Başından yumruk indirmemek: Sürekli eziyet etmek.

Yumruk indürmez başından ben gedânuñ şeş-perün

Zahmuma kan agladur ey meh dil ile hançerüũ (G.259/1)

Başını alıp gitmek/kaçmak (G.13/3, G.327/1): Kimseye danışmadan, haber vermeden ve gideceği yeri söylemeden ortadan kaybolmak (ÖAA: II/623; EKE: II/66-67; IP: II/159; AP: 152; MES: I/188; MAT: 46). 
Başını ezmek (G.127/1): Birini kımıldanamaz, canlanamaz ve kötülük yapamaz duruma sokmak (ÖAA: II/624; EKE: II/68; İP: II/160; AP: 153; MES: I/189; MAT: 47).

Başını kavgaya vermek: Kavgaya karışmak, tartışmak (EKE: II/68).

Fem-i cânâne içün kim ki cidâl eyler ise

Emriyâ yok yire ol başını gavgâya virür (G.143/5)

Başını vermek (G.188/5): Ülküsünü gerçekleştirmeye çalıştı̆̆ı için öldürülmek, ölümü göze almak, kendini feda etmek (ÖAA: II/625; EKE: II/69; IP: II/161; AP: 154; MES: I/190; MAT: 51).

Baştan ayağa (G.17/2, G.227/4, G.242/4): Baştan aşağ1, baştan sona kadar, bütünüyle (ÖAA: II/628; EKE: II/70; IP: II/30; AP: 157; MES: I/192; MAT: 50).

Baştan çıkarmak (G.74/2): Ayartmak, doğru yoldan çıkarmak, kötü yola sürüklemek (ÖAA: II/628; EKE: II/70-71; IP: II/164; AP: 157; MES: I/193; MAT: 51).

Baştan çıkmak (G.510/1): Doğru yoldan ayrılmak, ahlâkı bozulmak, kötü yola sürüklenmek (EKE: II/71-72; İP: II/164; AP: 157; MES: I/193).

Baştan gitmemek (K.2/23): Başından atamamak, kurtulamamak.

Başmağı/pabucu dama atılmak: Gözden düşmek, ikinci plana itilmek, artık değer verilmemek (ÖAA: II/1001; EKE: II/355; IP: II/701; AP: 649; MES: I/947; MAT: 209).

Hilâli añma anuñ başmagı tama atılmışdur

Gümiş na'leynüñe irmez güneş başmaguña degmez (G.212/3)

Belaya düşmek (G.83/2): Çok kötü bir durumla, beklenmeyen bir bela ile karşılaşmak (ÖAA: II/631; EKE: II/74; İP: II/170; AP: 161; MES: I/198).

Belaya girmek/uğramak: bk. Belaya düşmek.

Belini bükmek (G.243/4): Büyük üzüntü ve çaresizlik içinde bırakmak (ÖAA: II/632; EKE: II/75; IP: II/169; AP: 162; MES: I/199; MAT: 57). 
Benzi sararmak (Müst.1/4, G.277/3, G.290/2, M.1/2, M.11/2, M.151/1): Sıkıntıdan, üzüntüden veya korkudan yüzünün rengi değişmek (EKE: II/76; İP: II/173; MES: I/202). Ayrıca bk. Yüzü sararmak.

Benzi uçmak (M.466): Korkudan, heyecandan birdenbire benzi sararmak; yüzünün rengi solmak (ÖAA: II/635; EKE: II/76; İP: II/173; AP: 165; MES: I/202).

Benzinde kan kalmamak (M.328/2): Yüzü sararıp solmak (İP: II/173; AP: 165).

Berk yüzlü (G.190/4): Utanması olmayan; nerede ne yapacağını bilmeyen; hoş olmayan davranışlar sergileyen.

Gül 'ârızuñla olsa mu'ârzz 'aceb degül

Bir berk yüzlü ne edeb ü ne hayâsı var (G.87/3)

Bıçağa düşmek (G.237/1): Ölmek, hayatına son vermek (EKE: II/77).

Müjemde eşk-i merdüm-zâdum ey yâr

Cefâya döymeyüp düşdi bıçaga (G.483/4)

Bir alay (G.183/3, G.545/2, M.488): Bir sürü, pek çok (AP: 175; MES: $\mathrm{I} / 214)$.

Bir arada (G.21/4, G.47/1): Topluca, hep birlikte (AP: 175; MES: $\mathrm{I} / 215)$.

Bir ara(llk) (M.247/1): Az bir süre; bir fırsat düşünce, işler arasında; geçmişte kalan bir zaman (ÖAA: II/642; AP: 175; MES: I/215).

Bir avuç (G.410/3): Bir avucu dolduracak kadar; az sayıda, çok az (ÖAA: II/642; İP: II/186; AP: 175; MES: I/216; MAT: 59).

Bir ayağı çukurda olmak: bk. Ayağı çukurda (olmak).

Bir bir (G.216/2): Ayrı ayrı, teker teker, birer birer (ÖAA: II/643; AP: 176; MES: I/217; MAT: 59).

Bir dahi/daha (G.39/2): İkinci kez, bir kez daha; hiçbir zaman, asla (ÖAA: II/644; AP: 178; MES: I/218).

Bir damla (katre) (G.43/2, G.80/1, G.320/1, G.323/3, G.324/4, G.338/4, G.484/5, M.18/2, M.69, M.71): (Sıv1 için) Pek az, az1- 
cık; (çocuk için) pek küçük, küçücük (ÖAA: II/645; AP: 178; MES: I/219).

Bir giydiğini bir daha giymemek: Çok sayıda giysisi olmak, sürekli farklı şeyler giymek (MES: I/221).

Sâkî şol mey kanı kim devrinde tâc-ı la'lden

Hî̧ bir kez geydügin bir dahi geymezmiş habâb (G.39/2)

Bir iki (G.61/4, G.77/5, G.98/5, G.111/5, G.153/5, G.162/1, G.231/3， G.248/1，G.256/5， G.282/4， G.306/1， G.392/4, G.448/3, M.103, M.428/2): Birden çok ama dörtten az sayıda, çok az sayıda, birkaç (ÖAA: II/647; AP: 181; MES: I/223).

Bir karış (G.245/1, G.245/4, G.469/1, M.389/2): (Boy için) Çok kısa; (alan için) çok az; (sakal için) çok uzun (EKE: II/82; AP: 182; MES: I/224).

Bir nice (G.10/3, G.184/2, G.522/2, G.543/5, M.28/1, M.170, M.460): Epey, bir hayli, birçok (AP: 183).

Bir olmak (G.270/1): Bir araya gelmek, işbirliği yapmak; söylemekten yorulmak (EKE: II/83; AP: 183; MES: I/226).

Bir parça (pâre) (G.59/3, G.281/5, G.469/5): Çok az, biraz, azıcık (AP: 184; MES: I/227).

Birbirine girmek (G.223/3, G.485/2, M.268/3): Aralarında kavga çıkıp birbirlerine şiddetle saldırmak; anlaşamamak, dövüşmek; karışmak, çözülmeyecek duruma gelmek (ÖAA: II/643; EKE: II/80; IP: II/195; AP: 177; MES: I/232).

Birine/bire bin katmak (G.78/5): Olan bir şeyi çok abartarak anlatmak, bir olayı ya da başkasının sözünü aktarırken birçok şey eklemek; bir konuyu çok abartmak (ÖAA: II/646; EKE: II/84; IP: II/189; AP: 179; MES: I/232-233).

Boğazını çengelde görmek: Bir kabahatinden dolayı asılmak.

Zülfüñe zer gösterüp cevlân urur tâvûs-ı bâg

Bir gün ola kim bogazın görevüz çengâlda (G.443/2)

Boğazını urganda bulmak: Bir suçundan dolayı idam edilmek.

Emrî dil-i miskînüñ o zülfe tolaşurmış

Bir gün sen anuñ bogazın urganda bulursin (G.405/5) 
Borç eylemek (G.551/5): Borç almak, borçlanmak (ÖAA: II/656; AP: 194; MES: I/243).

Boynunu urmak (G.446/1): Kellesini uçurmak, başını keserek öldürmek (ÖAA: II/660; EKE: II/88; İP: II/210; AP: 199; MES: I/249; MAT: 63).

Boyun eğmek/eğmemek (G.151/5, G.308/2, M.219/2): Kabullenmek, isteyerek veya istemeyerek uymak, katlanmak; muhtaç olmak (ÖAA: II/618; EKE: II/88; İP: II/210; AP: 201; MES: I/251; MAT: 62).

Burnundan gelmek/getirmek (G.95/3, M.288/3): Elde edilen güzel bir durumu, kazanılan güzel bir şeyi arkasından gelen kötü şeyler ve sıkıntılar yüzünden kendisine zehir etmek (ÖAA: II/665; EKE: II/90; İP: II/217; AP: 208; MES: I/260).

Can atmak (G.476/3): Çok arzu ettiği bir şeyi veya durumu elde etmeye çalışmak, bir şeye erişmeyi çok istemek (ÖAA: II/671; EKE: II/92-93; IP: II/224; AP: 215; MES: I/268; MAT: 66).

Can borcu (M.135/3): Canını kurtarana borçlu olmak (EKE: II/94).

Can çekişmek (G.111/3): Son nefesini vermek veya ölmek üzere olmak; tükenmek, bitmek (ÖAA: II/671; EKE: II/94; İP: II/225; AP: 216; MES: I/269; MAT: 67).

Can 1smarlamak: Ruhunu teslim etmek, ölmek (EKE: II/95; MAT: 71).

Cânı bir dil-rübâya ısmarla

Aradan çık Hüdâya ısmarla (G.506/1)

Can nakdini/metaını almak (G.277/1, M.407/2): (Allah) Öldürmek, ölümünü tayin etmek; canını verdirecek kadar memnun etmek; aşırı sıkıntıya sokmak (ÖAA: II/674; EKE: II/107; IPP: II/230; AP: 219; MES: I/279). Ayrıca bk. Canını almak.

Sâhibin bogazlayup alur metâ'-ı cânını

'Işk bâzârında bir bogaz kesendür hançeri (G.550/2)

Canı ağzına gelmek: Büyük bir felaket veya tehlike karşısında ölecekmiş gibi bir korkuya kapılmak; aşırı duygulanmak, çok he- 
yecanlanmak (ÖAA: II/672; İP: II/227; AP: 217; MES: I/274; MAT: 67).

Emrînün dün sanemâ agzına geldi cânı

Bir kez öpince seni la'l-i güher-bâruñda (G.452/5)

Can(1) çıkmak (G.5/5, G.204/1, G.541/3): Çok yorulmak veya bitkin duruma düşmek; ölmek, son nefesini vermek; yaptığ 1 bir işte çok güçlük çekmek (ÖAA: II/673; EKE: II/103; İP: II/227; AP: 218; MES: I/275; MAT: 68).

Canı sıkılmak (M.211): Bir iş yapamamaktan veya bir şeyle uğraşmamaktan dolayı sıkıntı duymak, huzursuz olmak; bir olaya üzülmek; huzuru bozulmak; öfkelenmek, k1zmak (ÖAA: II/676; EKE: II/103; IP: II/231; AP: 221; MES: I/276; MAT: 71).

Canına/yüreğine/içine ateş (od) düşmek (G.123/4): Çok büyük bir acının, üzüntünün etkisi içinde bulunmak; yüreği yanmak (ÖAA: II/869; EKE: II/105; İP: II/483; AP: 464; MES: I/631). Ayrıca bk. Yüreği yanmak.

Şem'-i bezmü̃ şu'lesi 'aksi degüldür câmda

Âteş-i la'lüñ gamından od düşüpdür cânına (G.507/2)

Can(ın)a geçmek/işlemek (G.373/4, G.381/1): Etkisi altına almak, çok etkilemek; söz, davranış, bir kimseye çok dokunmak; bir durumun acısını derinden duymak; içine işlemek (ÖAA: II/870; EKE: II/104-105; IP: II/229; AP: 465; MES: I/277; MAT: $68)$.

Derd okı peykânlarından cânuma geçdi benüm

Cânumı al ey ecel tek eyle bir dermân baña (G.16/4)

Can(1n)dan geçmek (G.188/5, G.393/5): Ölmek; ölümü göze almak; ölümü ister duruma gelmek (ÖAA: II/671; EKE: II/106; İP: II/230; AP: 217; MES: I/279; MAT: 72).

Canını acıtmak (G.66/5): Birine acı vermek veya onu rencide etmek; birinin gövdesinin herhangi bir yerini acitacak bir şey yapmak (ÖAA: II/674; EKE: II/107; İP: II/230; AP: 219; MES: I/279; MAT: 69). 
Canını almak (G.305/1, G.305/2, G.451/1, G.451/2, G.502/4): (Allah) Öldürmek, ölümünü tayin etmek; canını verdirecek kadar memnun etmek; aşırı sıkıntıya sokmak (ÖAA: II/674; EKE: II/107; IP: II/230; AP: 219; MES: I/279). Ayrica bk. Can nakdini/metainı almak.

Canını vermek (Tah.1/II-III, G.23/3, G.33/4, G.48/5, G.57/5, G.85/2, G.185/5, G.195/5, G.208/5, G.227/5, G.242/5, G.247/4, G.272/5, G.279/1, G.293/5， G.313/3， G.382/2, G.421/5, G.451/2, G.495/3, G.514/1, M.176): Ölmek; biri için kendini feda etmek, ölümü bile göze almak; hiçbir şey esirgememek; çok sevdiği ve istediği bir şeye aşırı düşkün olmak (ÖAA: II/675; EKE: II/107-108; IP: II/231; AP: 220; MES: I/280; MAT: 70).

Ciğer kebap olmak: Büyük acı yaşamak, yüreği yanmak, acı içinde kıvranmak (ÖAA: II/682; EKE: II/110; IP: II/242; AP: 229; MES: I/290).

Gözümüuñ yaşı şarâb oldı ciger pâre kebâb

'Ayş ü nûş eyleyici bir dil-i 'ayyâşum var (G.152/4)

Ciğeri yanmak (G.537/1): Büyük bir acıya uğramak, çok üzülmek; aniden büyük bir acı veya felaket ile karşılaşmak; çok susamak (ÖAA: II/682; EKE: II/111-112; IP: II/241; AP: 229; MES: I/290; MAT: 74).

Çâk-i girîbân etmek/eylemek: bk. Yaka yırtmak.

Çalmadık yer/kapı bırakmamak (M.124/1): Herkese, her yola başvurmak (AP: 234; MES: I/297).

Çok başlı (olmak) (G.115/2, G.119/1, G.406/6): Baş kaldırmak, söz dinlememek, istediği gibi hareket etmek; zalim, bir işte usta, dolandırıcı, hırsız (EKE: II/120; Çetinkaya 2009: 226-245).

'Âşıkñ öldür diyü yâruñ ayagına düşer

Fitnede çok başlu yok zülf-i 'abîr-efşân gibi (G.525/3)

Dağ üstü bağ: Keyfi yerinde olmak, her muradına ulaşmış olmak (EKE: II/122; MAT: 80).

Ben ol Mecnûn-ı şeydâyam ki mihnet kûhsârında Hayâl-i kadd ü hadd-i yâr ile dâg üzre bâgum var (G.197/2) 
Damga vurmak (G.224/2): Damgalamak, damga ile işaretlemek; iz birakmak (IP: II/275; MES: I/332).

Dem çekmek (G.346/2): Kuşlar, uzun süreli ve güzel ezgiler çıkarmak, ötmek; içki içmek (ÖAA: II/711; EKE: II/127; İP: II/283; AP: 267; MES: I/343; MAT: 82).

Dem urmak (G.92/5, G.567/5): Belli bir konu üzerinde konuşmak, fikir yürütmek; olmayacak ya da gücünü aşan bir konu üzerinde konuşmak; nefes etmek, okuyup üflemek (EKE: II/127128; IIP: II/284; AP: 268; MES: I/344; MAT: 82).

Derisine sığmamak: Gururlu davranmak, böbürlenmek, çok kibirli olmak (ÖAA: II/714; IIP: II/288; AP: 271).

Hâl-i pür mûyına beñzetdüm çün Emrî nâfeyi

Sıgmayı yazdı derisine ferahdan müşg-i çîn (G.377/5)

Dik gelmek (G.95/5, G.245/1): Karşı gelmek; boyun eğmeyip baş kaldirmak, kafa tutmak (EKE: II/134; MAT: 84).

Ey kara gözlü kirpügüñ üstüme dik gelür

Senden beni kesem mi sanur ol bıçag-ile (G.427/2)

Diken üstünde durmak (G.31/5): Sürekli tedirginlik duymak; her an kalkacakmış gibi oturmak (ÖAA: II/718; EKE: II/135; İ: II/294; AP: 276-277; MES: I/359).

Dil uzatmak (G.133/4, G.326/4, G.338/4): Laf atmak, sayg1sızca sözlerle birini kötülemek; iftirada bulunmak (ÖAA: II/723; EKE: II/136; IIP: II/301; AP: 284; MES: I/361; MAT: 88).

Dile gelmek (G.165/4): Hakkında dedikodu yapılmak, konuşulmak; önce konuşmazken konuşmaya başlamak (ÖAA: II/719; EKE: II/137; IP: II/296; AP: 279; MES: I/362).

Dili dolaşmak (G.554/6): Aşırı korku, heyecan, ateşli hastalık, sarhoşluk gibi durumlarda neler söyleyeceğini şaşırarıp karıştırmak; söyleyeceğinin düzeni bozulmak (ÖAA: II/720; EKE: II/138; IP: II/297; AP: 280; MES: I/364; MAT: 86).

Dilinden düşürmemek (M.471): Sürekli aynı kişi veya konu üzerinde konuşmak, diline dolamak (ÖAA: II/721; EKE: II/138; IP: II/298; AP: 281; MES: I/366; MAT: 86). 
Dilini kesmek (G.128/5): Konuşmamak, susmak, söz söylememek; susturmak (ÖAA: II/722; EKE: II/139; İP: II/299; AP: 282; MES: I/367; MAT: 87).

Diş bilemek: Birine kızarak kötülük yapmak istemek veya acısını çıkarmak için fırsat kollamak; öcünü almak için çok istek duymak (ÖAA: II/725; EKE: II/142; İP: II/304; AP: 286; MES: I/371; MAT: 88).

Kaddüñe öykündügin işitdi şimşâduñ meger

Kesmege 'ırkını anuñ erre dâyim diş biler (G.99/3)

Dokuz dolanmak (G.545/5): Her tarafı dolaşmak, çok dolaşmak, her yere bakmak (EKE: II/144-145).

Çarhı tokuz tolanur hüsnüñe hem-tâ görimez

Dün ü gün mâh cüdâ mihr-i cihân-tâb cüdâ (G.22/3)

Dudağını dişlemek: Çok şaşırmak, hayretler içinde kalmak, hayran olmak.

Goncalar içre degüldür jâle gördükde seni

Dişlemişdür hayretinden leblerini gülsitân (M.345/4)

Dünyayı (başına) dar eylemek (G.387/4): Bir kimseyi çok sıkıntılı bir duruma sokmak (EKE: II/152; MES: I/399; Türkçe Sözlük I: 655).

Ecel ter(ler)i dökmek (G.78/1. G.515/2): Tehlikeli bir durum karş1sında kalıp çok korkmak; zor duruma düşmekten bunalım geçirmek; kendini ölecekmiş gibi hissetmek (ÖAA: II/742; EKE: II/154; IIP: II/327; AP: 308; MES: I/405; MAT: 93).

Eğri oturup doğru konuşmak: Gerçeği ve doğruyu olduğu gibi söylemek (ÖAA: II/744; EKE: II/155; İP: II/330).

Ebrû-yı hamuñ kâmetüñe serv-i sehî dir

Egri oturur kendüsi ammâ sözi togru (G.421/4)

Eksik etmemek/eylememek (M.116/2, M.313/2): Her zaman bulundurmak; uzun ara vermemek (ÖAA: II/747; EKE: II/156; AP: 312; MES: I/411). 
Eksik olmamak (G.91/4, G.170/2): Her zaman bulunur olmak, her zaman var olmak (ÖAA: II/747; İP: II/333; AP: 313; MES: I/411; MAT: 95).

El altında (G.270/2): Her zaman kolayca bulunabilecek yerde, istenildiği zaman kullanılmak üzere hazır (ÖAA: II/748; EKE: II/157; İP: II/334; AP: 314; MES: I/412; MAT: 95).

El çekmek (G.115/4): Kararından vazgeçmek, karışmamak; yapmakta olduğu bir işi artık yapmama durumuna geçmek (ÖAA: II/749; EKE: II/158-159; İP: II/335; AP: 315; MES: I/414; MAT: 96). Ayrica bk. El yumak (yıkamak).

El sunmak (G.112/2, G.276/5, G.339/4, M.14/2): Elini uzatmak; yaklaşmak istemek (ÖAA: II/764; EKE: II/161; IP: II/349; AP: 331; MES: I/416; MAT: 102).

Dürc-i dîdemden hayâl-i yâr dürr-i ter siler

El sunar rahm idüp ol hûnî gözüm yaşın siler (G.99/1)

El uzatmak (Tah.2/V, G.119/4): Birine dokunmaya veya bir hakkı almaya kalkışmak; yardım etmek, destek vermek; kendisine ait olmayan bir şey üzerinde hak iddia etmek; el ile dokunmak (ÖAA: II/765; EKE: II/161; IIP: II/350; AP: 332; MES: I/417; MAT: 102-103).

El uzunluğu etmek/eylemek (G.295/3): Hirsızlık yapmak (EKE: II/161).

Zülfi el uzunligin eyler anuñçün ey göñül

Mühri altında tutar la'lin dehân-ı dil-rübâ (G.10/4)

El üstünde tutmak (G.308/1, G.403/1): Bir kimseye gerekli sayg1 ve sevgiyi göstermek (ÖAA: II/765; EKE: II/161-162; İP: II/350; AP: 332; MES: I/417).

El vermek (M.6, M.143/3): Yardımda bulunmak, destek çıkmak; tarikatlarda mürşit, müride başkalarına yol gösterme izni vermek; halk hekimliği gibi konularda yetki vermek (ÖAA: II/765; EKE: II/162; İP: II/350; AP: 332; MES: I/417; MAT: 104-105).

Geyinüp hırka-i miskîsin el virseydi ol kâkül

Olurdı ‘̈mri oldugınca dervîşi anuñ sünbül (M.288/1) 
El yumak: Kararından vazgeçmek, karışmamak; yapmakta olduğu bir işi artık yapmama durumuna geçmek; bir şeyle ilgisini kesmek (ÖAA: II/749; EKE: II/162-163; İP: II/335; AP: 332; MES: I/418; MAT: 103). Ayrıca bk. El çekmek.

Şebnem ü bâd ile sohbetden idüp istigfâr

Yine el yudı etek silkdi gülşende çenâr (M.208)

Elden ayağa düşmek: Ayak altına düşmek, sarhoş olmak (EKE: II/163).

Göñüm müjeñde câna varmış bıçaga düşmiş

Mey içüp anuñ içün elden ayaga düşmiş (G.237/1)

Elden bırakmamak/düşürmemek: bk. Elden komamak.

Elden düşmemek (G.536/3): Bir şeyle sürekli ilgilenmek, elde tutmak, sahip olmak (ÖAA: II/758; EKE: II/164; IP: II/336; AP: 316; MES: I/429; MAT: 100).

Elden gitmek (G.100/6): Yerine gelmemek üzere yitirilmek, ondan yoksun kalınmak; bir şeyi kaybetmek (ÖAA: II/751; EKE: II/164; IP: II/337; AP: 317; MES: I/420; MAT: 97).

Elden komamak (G.534/5, M.167/2): Bir şeyle sürekli ilgilenmek, elde tutmak, sahip olmak; ondan vazgeçmemek (EKE: II/164165; IP: II/336; MES: I/419).

Düşdüm ayaklara elden komadum yâr etegin

Gerçi yârum komadı bir nefes agyâr etegin (G.385/1)

Elden uçurmak: Elinden gitmek; elinden kaçmak, kaçırmak.

Murg-ı hüsnini nigâr elden uçurdı Emrî

Kara telden yine yapar aña hat bu kafesi (G.536/5)

Ele gelmek/gelmemek (G.107/2): El ile tutulabilir olmak, tutabilmek; elde etmek (ÖAA: II/752; EKE: II/165; İP: II/338; AP: 318; MES: I/421).

Ele girmek/girmemek (G.385/5): Ele geçmemek, elde edilmemek; ele geçmemek, elde edilmemek (EKE: II/165-166; MES: I/421).

Eli ayağı: Birinin her işine yarayan, yardımcısı (EKE: II/167; AP: 320; MES: I/423). 
Koma sâgarla sebû kulbinı elden Emrî

Zurefâ bezminüñ anlardur eli ayagı (G.534/5)

Eli değmemek (M.442/4): Bir işi yapmaya vakit bulamamak, fırsatı olmamak (ÖAA: II/756; EKE: II/167; IIP: II/341; AP: 322; MES: I/425; MAT: 99). Ayrica bk. Eli ermemek.

Eli ermek/ermemek (G.499/3, G.509/1): Bir işi yapmaya zaman ve fırsat bulmak; yapabilmek, ulaşabilmek; zaman ve firsat bulamamak; yapamamak, ulaşamamak (ÖAA: II/756; EKE: II/168; İP: II/341; AP: 322; MES: I/425; MAT: 100; Türkçe Sözlük I: 691). Ayrica bk. Eli değmemek.

Elinden kapmak (G.93/2): Elinden almak, birini sahip olduğu bir şeyden yoksun bırakmak; elinden ve iradesinden çıkmak (MES: I/429).

Eline girmek/geçmek (G.65/3, G.289/5): Ele geçirmek, elde etmek; kazanmak, bulmak, yakalamak (EKE: II/171; IIP: II/344; AP: 325-326; MES: I/431).

Elini göğsüne koymak: Ellerini göğsünde birleştirip sayg1 göstermek (EKE: II/171-172).

Rakîbe sanma ta'zîmen korm el gögsüme cânâ

Kef-i destümle andan dâg-ı 'işkuñ eylerin pinhân (G.388/4)

Elini kana sokmak/bulamak (G.20/2): Birini yaralamak veya öldürmek (ÖAA: II/760; EKE: II/172; İP: II/345; AP: 326; MES: $\mathrm{I} / 432)$.

Elif çekmek (G.6/2, G.67/1, G.88/3, G.168/2, G.193/3, G.205/2, G.222/3, G.301/3, G.431/3, M.153/1): Elif harfi gibi göğüste boylamasına yara açmak (MAT: 100).

Gögsüme çekdüm elif üstine yakdum tâze dâg

Sen gül içün lâlelerle sînem itdüm reşk-i bâg (M.241)

Engel olmak (G.335/2): Bir işin gerçekleşmesini önlemek, engellemek; bir işi geciktirmek (AP: 334; MES: I/438).

Esip savurmak/yağmak (M.246/2): Aniden kızarak etrafa korku salmak; azarlayıcı bir tavırla bağırmak (ÖAA: II/769; EKE: II/174; İP: II/356; AP: 337; MES: I/442). 
Eteğine yapışmak: bk. Eteğini elden komamak.

Eteğini elden komamak: Eteğine yapışmak, yardım istemek, koruyuculuğu altına girmek istemek (ÖAA: II/772; EKE: II/176; İP: II/360; AP: 341; MES: I/449).

Düşü̈m ayaklara elden komadum yâr etegin

Gerçi yârum komadı bir nefes agyâr etegin (G.385/1)

Etek silkmek: İlgilenmemek, üzerinde durmamak; uzaklaştı̆̆ını belirtmek (ÖAA: II/773; EKE: II/176; İP: II/339; AP: 341).

Şebnem ü bâd ile sohbetden idüp istigfâr

Yine el yudı etek silkdi gülşende çenâr (M.208)

Ezber eylemek (K.2/18): Ezberleyerek akılda tutmak (IP: II/366; MES: I/457-458).

Ezber(e) okumak (G.19/4): Bir yazıyı eksiksiz olarak ve bir yere bakmadan okumak (MES: I/458).

Fark edilmek/olunmak (G.328/2, G.473/4): Seçilip ayırt edilmek, ayrımsanmak; anlaşılmak; sezilmek (ÖAA: II/779; İP: II/369; AP: 349; MES: I/462; MAT: 108).

Fark etmek (G.378/2, G.394/2, M.484): Anlamak, sezmek, ayr1minda olmak; görmek, seçmek; eskisinden başka bir duruma gelmek, değişmek; farkını anlamak (ÖAA: II/779; EKE: II/178; İP: II/369; AP: 349; MES: I/462; MAT: 108).

Fursat beklemek/gözlemek/kollamak (G.210/1): Yapmak istediği iş için uygun bir zaman, durum ya da koşul oluşmasını beklemek, en elverişli durumu, koşulu, zaman kollamak (ÖAA: II/783; EKE: II/181; İP: II/376; AP: 354; MES: I/469-470).

Gam çekmek (K.1/9, G.15/1, G.231/2, G.297/1, G.369/1, G.502/5, M.1/2, M.474): Hüzünlenmek, tasalanmak, üzülmek (ÖAA: II/787; EKE: II/185; IP: II/382; AP: 362; MES: I/480; MAT: 110).

Gam yememek: Tasa etmemek, kaygı çekmemek, üzülmemek (ÖAA: II/788; EKE: II/185-186; IP: II/382; MAT: 110).

Nasîbi olmadugına halîlüm hân-ı vasluñdan İnanma gam yimem dirse rakîb it gibi cân besler (G.175/2) 
Gama düşmek (G.5/4): Hüzünlenmek, tasalanmak, acı çekmek (EKE: II/186).

Geceyi gündüze katmak (G.287/2): Sürekli, aralıksız çalışmak, gece gündüz dememek (ÖAA: II/789; EKE: II/187; İP: II/385; AP: 365; MES: I/485; MAT: 110).

Gen yakadan: Uzaktan, ıraktan; yaka bağır açık olarak (Çavuşoğlu 1998: 98-104; MAT: 111).

Bu ceyb-i çâk ile 'âşık geçinme geñ yakadan

Yarar sabâ sakın ey gül alur girîbânuñ (M.258/2)

Geri kalmamak (M.315): Yapmaktan çekinmemek, kaçınmamak, vazgeçmemek; birinden daha aşağı ve daha az başarılı olmamak (ÖAA: II/793; İP: II/390; AP: 370; MES: I/492; MAT: 112).

Gizli din tutmak/taşımak: Görünüşünden farklı bir inanca ve anlayışa sahip olmak (ÖAA: II/796; EKE: II/189; IP: II/393; AP: 374; MES: I/497).

Gizlü dîn tutardı zülfü̃ dime kim bî̀-dîn idi

Ey cemâli Ka'be nûr olsun yiri miskîn idi (G.527/1)

Göbeği düşmek: Göbek deliğinin kapanmasıyla göbeğinde fitık oluşmak (ÖAA: II/797; İP: II/393; AP: 375; MES: I/498).

Görince nâfe saçın didi âh $\hat{u}-y \imath$ müşgîn

Senün yükü̈n çekerin düşse gam degül göbegüm (M.306/3)

Göğsünü dövmek (G.473/1): Hayıflanmak, yazıklanmak (EKE: II/190).

Göğsünü germek (G.98/5): Hiçbir şeyden çekinmemek; kendine güvenmek; övünmek (ÖAA: II/798; EKE: II/190; İP: II/395; AP: 376; MAT: 113).

Gögüs germek (G.214/5, G.217/5): Pek çok güçlüğe karşı koymak, dayanmak, kendini siper etmek (ÖAA: II/798; EKE: II/191; İP: II/395; AP: 376; MES: I/500; MAT: 113).

Göklere çıkmak/ermek/erişmek (G.74/5, G.276/6, G.294/2): Pek çok yükselmek (EKE: II/190; AP: 377; MES: I/501).

Gönlüne getirmek (M.442/2): Gönlünde yer vermek. 
Zülfi sevdâsını göñlüme getürdüm Emrî

Mürdeyem sanki mezâruma iletdüm 'amelüm (G.349/5)

Gönlüne/kalbine girmek (G.142/2, G.278/2, M.264/2, M.448): Birinin sevgisini kazanmak, kalbine girmek (EKE: II/196; IPP: II/533; AP: 510; MES: I/505).

Gönlü kalmak (G.259/5): İsteyip de edinemediği bir şeyde hâlâ umudu olmak, gözü kalmak; gücenmek (ÖAA: II/800; EKE: II/194; İP: II/397; AP: 378; MES: I/503; MAT: 115).

Gönlünü ele almak (G.282/5, G.559/3): İltifat etmek, güleryüz göstermek, ilgilenmek (EKE: II/194; MAT: 121).

'Ukde-i kalbin açar her gâh alup göñlin ele

Zülf-i müşgîn zîr-i desti olmasun mı şânenü̈ñ (M.262/3)

Gönlünü kapmak/kaptırmak (G.93/2): Birine tutulmak, âşık olmak; birini aşırı derecede sevmek (ÖAA: II/803; EKE: II/197; İP: II/398; AP: 379; MES: I/505).

Gönül açmak (G.468/1): İnsanın iç sıkıntısını ortadan kaldırmak, iç açmak (ÖAA: II/802; EKE: II/193, 197; İP: II/399; AP: 380; MES: I/506; MAT: 117).

Gönül (dil) bağlamak (G.104/2, G.453/3, G.467/2, G.486/2): Tutulmak, yürekten sevmek, sevgi ile bağlanmak (ÖAA: II/803; EKE: II/199; IP: II/399; AP: 380; MES: I/506; MAT: 120). Ayrica bk. Gönül (dil) vermek.

Gönül (dil) vermek (Tah.1/II, G.110/4, G.295/1, G.417/4): Birine tutulmak, âşık olmak, aşkla bağlanmak (ÖAA: II/803; EKE: II/202-203; İP: II/401; AP: 382; MES: I/509; MAT: 121). Ayrıca bk. Gönül (dil) bağlamak.

Gönül yıkmak: Birini çok üzecek ve yürekten acıtacak bir davranışta bulunmak, gücendirmek, gönül kırmak (EKE: II/203-204; IIP: II/401; MAT: 121).

Yâr yıksa göñlüñi gam çekme ey âşık sevin

Seng-i bî-dâd ile bünyâd eylemek ister evin (G.369/1) 
Gönülden (dilden) çıkarmak (G.131/5): Artık sevmez, anmaz olmak; sevgisini sürdürmemek (ÖAA: II/802; EKE: II/204; AP: 381; MES: I/509).

Reh-i tecrîde sâlik ol çıkar sûzen gamın dilden

Getürme göñüüne ya'nî hayâl-i gamze-i yârı (M.442/2)

Gönülden (dilden) geçmek/geçirmek (G.98/4, G.127/3, G.545/1): Bir şeyin olmasını veya bir şey yapmayı istemek; aklından geçirmek, düşünmek, tasarlamak (EKE: II/204; İP: II/397; AP: 379; MES: I/504; MAT: 115).

Gönüllü gönülsüz: Yarı istekli yarı isteksiz, pek istekli olmayarak (AP: 382).

Gönül götürürdi kapuña varmaga zâhid

Varur gelür oldı hele göñüllü göñülsüz (M.218/3)

Gönül(ünü) almak (G.236/1, G.486/2, M.191/1): Birini sevindirmek; kırılan bir kimseyi güzel sözle, uygun davranışla, bir armağanla hoşnut etmek (ÖAA: II/802; EKE: II/198; İP: II/399; AP: 380; MES: I/505; MAT: 119-120).

Görecek gözü olmamak: Görmek istememek, nefret etmek; dikkati belirli bir noktaya bağlamak ve onun dışındaki şeyleri görmemek (EKE: II/205; AP: 382; MES: I/509).

Revzeninden göreli yâr nazar-bâzlıgın

Göricek gözleri yok çeşm-i güher-bârı göñül (G.307/4)

Görünmez kaza (M.282/1): Hiç umulmadık, beklenmedik zamanda ve biçimde başa gelen kaza (EKE: II/205; AP: 384; MES: I/510).

Göz/nazar değmek (G.433/4, G.467/1, G.564/5, M.421/2): Uğursuzluk, kötülük getirdiğine inanılan, kıskanç ya da hayran bakışlar dolayısıyla fena bir duruma düşmek, nazara gelmek (ÖAA: II/807; EKE: II/207; İ: II/405; AP: 388; MES: I/514; MAT: 123). Ayrıca bk. Göze gelmek.

Göz boncuğu (G.266/5, G.433/4, G.504/4, M.421/2): Göz değmesin diye takılan, göz biçiminde ve mavi renkli boncuk; nazar boncuğu (EKE: II/207; AP: 388; MES: I/514). 
Göz boyamak (M.212): Kötü bir şeyi iyi gibi göstererek aldatmak, kandırmak, avutmak (ÖAA: II/807; EKE: II/207; IP: II/405; AP: 388; MES: I/514; MAT: 122).

Göz dikmek (G.219/1): Bir şeyi her halde ele geçirmek istemek; ona sürekli olarak bakıp durmak (ÖAA: II/808; EKE: II/207-208; IP: II/406; AP: 401; MES: I/514; MAT: 124).

Göz etmek/eylemek (G.41/2, G.304/1, M.14/1, M.421/1): Göz işaretleriyle isteklerini anlatmak, gözle işaret vermek (ÖAA: II/809; EKE: II/208; AP: 390; MES: I/515; MAT: 124).

Göz göre (G.295/1): Herkesin gözü önünde, açıça (ÖAA: II/810; EKE: II/208; IIP: II/407; AP: 390; MES: I/515).

Göz kırpmak (G.49/1): Göz kapağını kapatıp açmak; göz açıp kapayarak işaret vermek (ÖAA: II/810-811; EKE: II/209; İP: II/408; AP: 391; MES: I/516).

Göz kulak olmak (G.439/3): Korunması gereken kimseyi ya da şeyi görüp gözetmek; kollamak, bakmak; görme ve işitme yoluyla öğrenmeye, bilgi edinmeye çalışmak (ÖAA: II/811; EKE: II/210; İP: II/409; AP: 391; MES: I/516; MAT: 125).

Göz nuru dökmek: İnce, değerli bir ürün meydana getirmek için gözleri çok yoran bir dikkat ve titizlikle uzun süre çalışmak ve iş üretmek (ÖAA: II/813; EKE: II/210; İP: II/412; AP: 395; MES: I/517).

Şol kadar dökdüm ruhı nakşında göz nûrın gice

Yir yüzi agarmış idi geldi ol hurşî̀-veş (M.238/2)

Gözden çıkarmak (G.162/3): Bir malının gitmesine razı olmak, yokluğuna katlanmak, elden çıkarmaya hazırlanmak (ÖAA: II/808; EKE: II/21; IP: II/405; AP: 388; MES: I/518).

Gözden (nazardan) düşmek (M.478/3): Eski itibarı kalmamak, sevgi ve ilgiyi yitirmek (ÖAA: II/808; EKE: II/213; İP: II/406; AP: 388; MES: I/518).

Gözden savmak (G.335/2): Gönülden çıkarmak, artık sevmez ve anmaz olmak; görmek istememek (MAT: 132).

Harîm-i çeşmüñe koyma gelürse an gözden sav

Saña gaflet virür 'ömrüñ ugurlar kalma hâb ile (G.475/4) 
Göze/nazara gelmek (G.32/4): Nazar değmek, kötülüğe uğramak (ÖAA: II/807; EKE: II/214; İP: II/405; AP: 390; MES: I/520). Ayrıca bk. Göz değmek.

Gözle yemek (G.377/3): Birine, bir şeye aşırı istekle ve dik dik bakmak, gözlerini ondan alamamak; göz değdirmek (ÖAA: II/813; EKE: II/214; IP: II/420; AP: 395; MES: I/520; MAT: 126).

Yaralar gözle yidiler bu ten-i mecrûhumı

Sînesine çekdi diyü hançerin cânânenü̃̃̃ (M.262/2)

Gözleri açık kalmak: Gerçekleşmesini çok istediği bir arzusuna ulaşamadan ölmek (ÖAA: II/814; EKE: II/216; İP: II/413; AP: 395; MES: I/526).

Hasret ile ölse 'âşık kalsa açuk gözleri

Dirile tuş olsa çeşmi ger leb-i cânânuma (G.445/4)

Gözü açık gitmek: bk. Gözleri açık kalmak.

Gözünüz aydın (G.416/6): Kavuştuğun sevinçli gün ya da sevindirici olay kutlu olsun, tebrik ederim (ÖAA: II/818; EKE: II/217; IIP: II/416; MES: I/532).

Gözü görmemek (G.406/2, G.526/2): Çok beğendiği veya istediği bir şeyden başkası ile ilgilenmemek; öfke ve kızgınlıktan dolayı en kötü şeyleri yapabilecek duruma gelmek (ÖAA: II/816; EKE: II/217, 223; IP: II/415; AP: 397; MES: I/528).

Gözü kanlı (G.421/6): Çok öfkeli, gözünü kan bürümüş; katil (EKE: II/218; MES: I/529).

Hûn-ı sirişk ü nâl-i dil ile benüm bu gün

Yalı̃̃ yaraklu bir gözi kanlu dil-âveri (G.515/4)

Gözü önünde (G.360/5): Gözleriyle görmek, bizzat şahit olmak.

Gözünde olmamak: bk. Gözüne ('aynına) gelmemek.

Gözüne gelmek: Bir şeyi zihinde canlandırmak, tasarlamak, hatırlamak; görür gibi olmak (EKE: II/223; AP: 403; MES: I/538).

'Aks-i la'li gözde iken na' ra-i mestânemi

Gûş idüp dimiş gözine geldi Emrînüñ serâb (G.43/5) 
Gözüne ('aynına) gelmemek (G.209/2, G.338/4): Söz konusu şeye sahip olma tutkusu içinde bulunmamak; önem vermemek; hiçbir şeye değer verecek durumda olmamak (ÖAA: II/819; EKE: II/223; IP: II/416; AP: 399; MES: I/532).

Dâg-ı gamdur cânuma bâg-ı cinânuñ gülleri Âb-ı Kevser 'aynuma gelmez leb-i dil-dârsuz (G.209/3)

Göz(ün)e girmek (G.278/2, M.264/2): Hareketleriyle ve yetenekleriyle herkesin ilgisini çekmek; sevgi, önem ve güven kazanmak; kendini aşırı derecede beğendirmek (ÖAA: II/809, 819; EKE: II/214; IP: II/407, 417; AP: 390, 400; MES: I/520, 533-534).

Gözünü açmak (G.8/6, G.531/2, G.566/1): Uyanık ve dikkatli olmak; bir kimseyi uyararak gerçekleri görmesine yardımcı olmak (EKE: II/224-225; MES: I/534; MAT: 130).

Gözünü kan boyamak/bürümek (G.198/5): Gözleri kan çanağına dönmek; birini öldürecek kadar öfkelenmek (ÖAA: II/821; EKE: II/226; IP: II/418; AP: 402; MES: I/536; MAT: 130).

Gözünün önüne gelmek: bk. Gözüne gelmek.

Gözyaşı dökmek (G.119/5, G.284/2, G.376/1, G.465/3): Ağlamak (ÖAA: II/824; İP: II/420; AP: 405; MES: I/538; MAT: 132).

Gözyaşııı silmek (G.99/1, G.201/2, G.333/6, G.349/4, M.112): Ac1mak, yardımda bulunmak (EKE: II/227).

Gün görmek (G.334/3): Bolluk, esenlik, rahat ve huzur içinde yaşamak (ÖAA: II/828; EKE: II/229; IP: II/426; AP: 411; MES: I/544; MAT: 135).

Gün görmemek (M.60/3): Dert ve sıkıntı içinde yaşamak; rahat ve mutluluk yüzü görmemek (ÖAA: II/828; EKE: II/229; IP: II/426; AP: 411).

Gün göstermemek (G.537/3, M.119): Rahat yüzü göstermemek, dert ve sıkıntı içinde yaşatmak (EKE: II/229; MES: I/544).

Günah işlemek (G.251/3): Günah sayılan davranışlarda bulunmak, günaha girmek (ÖAA: II/827; EKE: II/230; IP: II/428; AP: 409; MES: I/545). 
Günahı (yazugu) boynuna (G.269/3): Sorumluluk bende değil! Ben karışmam; bu bir suç ise sorumlusu odur (ÖAA: II/826; EKE: II/230; IP: II/428; AP: 409; MES: I/546).

Haber almak (G.298/4, M.79/1): Bilgi edinmek, (bir durum) bilgi olarak kendisine bildirilmiş olmak, kendisine haber ulaşmak (ÖAA: II/833; IP: II/434; AP: 416; MES: I/554; MAT: 137).

Haber göndermek (G.193/4, M.196): Bilgi ulaştırmak, herhangi bir araçla bilgi sunmak veya iletmek (IP: II/434; MES: I/554).

Haber vermek (G.76/2, G.295/4, G.309/3, G.467/3, M.334/1, M.395/1, M.441, M.453/2): Bir durumu bildirmek, duyurmak; bir olayın, bir durumun belirtisi olmak (ÖAA: II/833; IP: II/434; AP: 417; MES: I/555; MAT: 137).

Hâk ile yeksan eylemek: (Yapı şehir vb.) Temelinden yıkıp harap etmek veya olmak; yerle bir etmek (ÖAA: II/1117; EKE: II/234; IP: II/437; AP: 420; MES: I/559; MAT: 139). Ayrıca bk. Hâke yeksan eylemek.

Her dirahtı çemenü̃ mâlik-i dînâr-durur

Zeri ger hâk ile eylerse 'aceb mi yeksân (K.1/13)

Hâke yeksan eylemek: (Yapı şehir vb.) Temelinden yıkıp harap etmek veya olmak; yerle bir etmek (ÖAA: II/1117; EKE: II/234; IP: II/437; AP: 420; MES: I/559; MAT: 139). Ayrıca bk. Hâk ile yeksan eylemek.

Ben gubârı hâke yeksân eylemişdür dest-i gam

Bâd-ı âhum lutf idüp geldi götürdi hâkden (G.376/4)

Haram olmak (M.350): Bir şeyden gerektiği gibi yararlanamamak, bir şey eline geçmez olmak; uygun düşmemek (ÖAA: II/842; IP: II/446; AP: 427; MES: I/571; MAT: 140).

Hararet vermek (G.536/3): Vücut 1sısını yükseltmek; susatmak (ÖAA: II/842; EKE: II/238; IPP: II/446; AP: 428; MAT: 141).

Harca sürmek (M.99): Telef etmek, harcamak, öldürmek (MAT: 140).

Gördi gam basmış ten-i pür-dâgumı gerd-i fenâ

Harca sürmek istedi gencîne-i medfûn sanup (G.51/2) 
Harf atmak: Söz söylemek, söz atmak, laf atmak; uzaktan dokunacak söz söyleyip işittirmek (ÖAA: II/843; EKE: II/238; İ: II/447; MES: I/572; MAT: 140).

Togrısına yañuldum okına elif didüm

Harf atdı Emriyâ baña ol kaşları kemân (G.354/5)

Hayal olmak (G.303/2): Gerçekleştirilememek, gerçekleşmesi sağlanamamak; geçmişte kalmak, hatıra olmak (IP: II/455; AP: 437; MES: I/585).

Hayran kalmak (G.14/3, M.422): Güzel durumu ya da davranışları karşısında beğeni duymak, takdir etmek (EKE: II/242; MES: I/590).

Hayrete batmak (G.13/2): Çok şaşırmak, şaşırıp kalmak (IIP: II/458; AP: 440; MES: I/590).

Hayrete düşmek: bk. Hayrete varmak, Hayrete batmak.

Hayrete varmak (G.354/3, G.359/4, G.382/3, G.422/3): Çok şaşırmak, şaşırıp kalmak (İP: II/458; AP: 440; MES: I/590).

Görüp mâh-ı nev-i ebrûñ ahşam hayrete varmış

Dehân-ı çarhda ey meh hilâl engüşt-i hayretdür (G.158/3)

Hiçe gitmek: Yok yerine sayılmak, yok gibi olmak.

Ölicek hîçe gider geçsün dir iseñ mihnete

Emriyâ cânı leb-i cânânuma vir dirile (G.446/5)

Hisse almak (G.530/5): Pay çıkarmak, yararlı bir ders almak (İP: II/470).

Hoş geldin (G.442/4): Bir yere yeni geleni karşılarken söylenen nezaket, esenleme sözü (ÖAA: II/860; İP: II/472; MES: I/610).

Hoş görmek (G.288/5): Toleranslı davranmak, kusuru sorun yapmamak, anlayışla karşılamak (ÖAA: II/860; EKE: II/247; İ: II/472; AP: 454; MES: I/610-611; MAT: 146).

Hoş tutmak (G.15/7): Birinin gönlüne göre davranmak, incinmemesine dikkat etmek (ÖAA: II/861; EKE: II/247; IP: II/472; AP: 454; MES: I/611; MAT: 146). 
Irkını kesmek: Soyunu kurutmak.

Kaddüñe öykündügin işitdi şimşâduñ meger

Kesmege 'ırkın anuñ erre dâyim diş biler (G.99/3)

İçi dışına uymamak: İçi başka, dışı başka olmak; göründüğü gibi olmamak (EKE: II/251).

Zerd-rûyını görüp sanma derûnı hâlîdür

Uymaz ey gonca gül-i ra'nânuñ içi taşına (M.383/2)

İçine (ciğerine, yüreğine) işlemek: bk. Can(ın)a geçmek.

İçinin yağı dökülmek/erimek (G.535/2): Korkulacak bir durum meydana gelecek diye kaygı çekmek, derinde üzülmek (ÖAA: II/871; EKE: II/253; IP: II/937; AP: 466; MES: I/634).

İğne yutmuş ite dönmek (M.20): Bitkin duruma düşmek, aşırı derecede zayıflamak (ÖAA: II/874; EKE: II/254; İ: II/489; AP: 469; MES: I/638; MAT: 149).

Fikr-i müjgânun düşelden kalbine

İgne yutmış kelbe dönmişdür rakîb (G.48/3)

İkide bir (M.131/4): Sıkça, sık olarak (ÖAA: II/875; EKE: II/257; IPP: II/492; AP: 470; MAT: 150).

İki büklüm (olmak): bk. İki bükülmek.

İki bükülmek (G.22/4, G.434/2): Yaşlılık, hastalık, sayg1 gösterme gibi nedenlerle beli beli bükülmek; iki kat olmak (ÖAA: II/875; EKE: II/255; IP: II/491; AP: 470; MES: I/640).

Çarh-ı ser-keş dest-i âhumdan zebûn olmış-durur

Kâmeti iki bükilmiş bagrı hûn olmış-durur (G.118/1)

İkrar eylemek (G.502/4): Açık açık söylemek, dile getirmek (İP: II/494).

İliğini/kanını kurutmak (M.279/1): İnsanı canından bezdirecek ölçüde sıkıntı ve eziyet vermek (ÖAA: II/905; EKE: II/257; İP: II/496; AP: 474; MES: I/648; MAT: 151).

İmana gelmek (G.302/4): İslâm dinini kabul etmek; en sonunda gerçeği dile getirmek; baştan karşı çıktığı bir şeyi sonradan be- 
nimsemek (ÖAA: II/879; EKE: II/258; IIP: II/497; AP: 476; MES: I/651; MAT: 151).

İnsafa gelmek (G.201/3, G.263/4): Olumlu ve 1lımlı yaklaşmak; öfkesi yatışmak, acımasız tutumunu bırakmak (EKE: II/260; IP: II/501; MES: I/656).

İş asmak: Üstün olmak, üstün görünmek (MAT: 153).

Emrî rakîbi as resen-i dûd-ı âh ile Maksûd bir iş asmak ise rûzgârda (G.501/5)

İşini bitirmek (G.165/5): Yapılması kendisinden beklenen işi sona erdirmek; birini artık iş yapamayacak güçsüzlüğe uğratmak; öldürmek, hayatına son vermek (ÖAA: II/887; EKE: II/265; İP: II/509; AP: 488; MAT: 154).

İt canlı: Bütün sıkıntılara ve acılara katlanabilen (ÖAA: II/891; EKE: II/266; IP: II/513; AP: 493; MES: I/679).

Rakîbün itine cânum diseñ incinmezüz zîrâ

Biz ey âhû ezelden bilürüz it cânludur agyâr (G.150/3)

İyilik görmek/görmemek (G.304/5, G.406/7): Maddî ve manevî anlamda yardım almak; almamak (İP: II/516; MES: I/684).

Kalbini (kalp şişesini) kırmak (G.558/3): Söylediği bir sözle ya da davranışlarıyla bir kimseyi incitmek, gücendirmek, üzmek (ÖAA: II/900; EKE: II/272; İP: II/533; AP: 510; MES: II/710; MAT: 157-158).

Kalem çekmek (G.463/5): Bir yazının, bir kaydın gereksiz ya da geçersiz olduğunu belirtmek üzere üstünü çizmek; kalemle yazmak (EKE: 273; İP: II/531; AP: 511; MES: II/712).

Ben ol sultân-ı 'ışkam dûd-ı âhumdan 'alem çekdüm

Melâmet defteri erkâmına evvel kalem çekdüm (G.346/1)

Kalem parmaklı: Parmakları güzel, düzgün, buruşuksuz ve uzunca (kimse) (EKE: II/273; AP: 512; MES: II/712).

Bir kalem barmaklu âfetdür kamış okuñ senüñ

Öldüri yazdı beni bir niçe kez ey kaşı yâ (G.10/3) 
Kalem yürütmek/oynatmak (G.408/5): Yazı yazmak; bir yazıyı düzeltmek; yazılmış bir yazı üstünde değişiklik yapmak (ÖAA: II/901; EKE: II/273; IP: II/531; AP: 512; MES: II/712).

Yazılmışda bozılmış çünki yokdur neyki ey Emrî

Kalem yüritdügi başumda tîri ol kaşı yânuñ (G.277/5)

Kan tutmak (K.2/8, G.557/3): Kan görünce bayllmak; adam öldüren kimse, şok geçirmek, dizinin bağ1 çözülüp cinayet yerinden kaçamamak; ansızın ölmek (ÖAA: II/907; EKE: II/279; IP: II/539; AP: 519; MES: II/720; MAT: 161).

Kan ağlamak (Tah.1/IV, G.114/4, G.127/2, G.203/1, G.247/5, G.259/1，G.298/3， G.303/5，G.322/2, G.323/1, G.336/3, G.345/3, G.352/4, G.383/1, G.393/4, G.408/1, G.471/3, G.523/1, G.567/3, M.1/2, M.236/2): Derin ac1 ve üzüntü duymak, içi yanmak, çok yakınmak (ÖAA: II/903; EKE: II/274-275; İP: II/535; AP: 515; MES: II/717; MAT: 158).

Kan bahası: Birini yaralayan ya da öldürenden alınıp yaralanan ya da ölenin ailesine verilen para, diyet, kan ödeği (EKE: II/276; MAT: 158).

Şol bâde kim şebîh-i leb-i cân-fezâsı var

Bir katresi hezâr Cemüñ kan bahâsı var (M.69)

Kan bahasını almak: Kan diyetini, kan borcunu almak (EKE: II/276).

La'lüñe öykünmegin emdi meyi bir bâde-nûş

Kan bahâsın aldı ammâ hürmet itdi mey-fürûş (M.227/1)

Kan dökmek (G.110/5, G.241/5, G.360/3-4, G.403/3, G.417/2, G.418/4, G.496/1, M.118, M.154, M.336/2): Yaralamak ya da ölüme yol açmak, cana kıymak; yaralanmak ya da ölmek (ÖAA: II/904; EKE: II/276; İP: II/536; AP: 516; MES: II/718719; MAT: 159).

Kan kusmak (G.58/3): Derinden ve ruhen çok acı, sıkıntı ve eziyet çekmek (ÖAA: II/906; EKE: II/278; IP: II/538; AP: 518; MES: II/719; MAT: 160). 
Kan ter içinde kalmak/Kan tere batmak: bk. Kan terlemek.

Kan terlemek (G.392/5, M.248/2): Çok terlemek; sırılsıklam ter içinde kalmak (ÖAA: II/907; EKE: II/279; İP: II/539; AP: 519; MES: II/720).

Jâle degül ey Emrî görüp rûy-ı nigâr

Kan terledi utandı kızardı gül-i ahmer (G.176/5)

Kan yalaşmak: Eski bir geleneğe göre kardeş olmak için iki kimse birbirinin birer damla kanını yalamak (EKE: II/280; MAT: 161).

Kan yalaşup lebüñ ile sâgar

Oldilar ey sanem birâderler (M.192/1)

Kan yutmak (G.389/5, G.538/2, M.118): Acıya ve eziyete dayanmak, tahammül etmek; bir sebeple çok acı ve eziyet çekmek (EKE: II/280-281; MES: II/721).

Kana boyamak/bulanmak (G.3/4, G.22/2, G.145/5, G.162/5, G.349/4, G.471/5, M.150): Kan içinde bırakmak, kanla doldurmak (EKE: II/281, 312; IP: II/535; AP: 515; MES: II/721). Ayrıca bk. Kana yumak.

Kana yumak (G.122/5, G.264/1, G.269/8, G.295/2, G.337/3, G.376/2, G.462/1, G.512/1, G.567/3): Kan içinde bırakmak.

Emrî gonca lebine öykündi

Agzını kana yudı bâd anũ̃ (G.287/5)

Kanı kurumak: Bıkmak, usanmak; bitkin, cansız duruma gelmek (EKE: II/284; MES: II/723).

La'lüñ öykündügini leblerüñe işidicek

Gevdesinde kurıdı kanı 'akîk-i Yemenüñ (G.271/3)

Kan(1n)a girmek (G.86/2, G.446/1, G.482/5): Birinin öldürülmesine sebep olmak veya öldürtmek; bir şeyi ziyan etmek; kandırmak (ÖAA: II/905; EKE: II/281-282; İP: II/537; AP: 517; MES: II/724; MAT: 164).

Kanına hat getirmek: Ölüm fermanını getirmek (MAT: 159). 
Kâmetüñ bâlâdur ey servüm miyânuñdur vasat

Safha-i güldür 'izâruñ leblerüñ müsşîn nukat

Levh-i dilden yuyamaz hattuñ eger olursa şat

La'lǖ̃ üzre yazdı Kevser sûresin gîyâ galat

Kim kazıtdr ey cemâli mushafum safhañda hat

Kanına 'âş̧ılaruñ la' lüñ getürdi çünki hat

Bir gün ola Emrî içün diyeler ey sebz-hat

Bir hatı sebzüñ gamından dil-figâr olmış-durur (Müs.1/V)

Kanına kanıkmak/susamak: Ölümüne yol açacak denli tehlikeli şeyler yapmak, belasını aramak; öldürmeyi isteyecek kadar birine düşman olmak (ÖAA: II/905; EKE: II/286; İP: II/537; AP: 517; MES: II/724; MAT: 164).

Mey kanıkmış gussanuñ kanına bir hûnî diyü

Gam hisârı kal'a bir tôp-ı hevâyîdür habâb (G.37/4)

Kanına kast etmek (G.445/3): Kanını dökmek istemek (EKE: II/286).

Kanını helal etmek: Canını vermeye, kanını onun için dökmeye hazır olmak (EKE: II/287).

Ne kanlu demdür ol dem kim çeküp şemşîr-i müjgânuñ

Harâmî gözlerü̈̃ diye hemân kanuñ helâl eyle (G.477/4)

Kan(ını) içmek (G.41/2, G.80/2, G.320/1, G.354/4, G.482/3, G.499/4, G.557/3): Birini öldürmek; kan dökmekten çekinmemek, bunu hirsla yapmak (EKE: II/277-278; MES: II/719, 724).

Kanını yerde komamak: Öcünü almak (MES: II/724).

Kaldurur kanumla âlûde görüp dâmânını

Bilürüz hak yirde komaz ehl-i 'ışkuñ kanını (M.479/1)

Kanlı (G.435/4, M.154, M.192/2): Kan dökücü, katil; kan davalısı.

Kanlı bıçaklı olmak: Aralarında büyük bir kan davası olmak, birbirini öldürecek kadar düşman olmak (ÖAA: II/906; EKE: II/288289; IP: II/540; AP: 518; MES: II/724; MAT: 164).

Hayâlin gamzesin tenhâ görürsin diyü ey Emrî

Müjem kanlu bıçaklu oldı çeşm-i hûn-feşân ile (G.476/5) 
Kapısı açık (olmak) (G.275/4): Herkesle barışık olmak; her isteyen evine konuk gelmek (ÖAA: II/908; EKE: II/290; IP: II/543; AP: 522; MES: II/729).

Kara baht (baht-1 siyâh) (G.159/5, G.558/2): Kötü talih (EKE: II/291-292; MES: II/731).

Kara bahtlı (G.327/3): Şanssız, kısmetsiz (MES: II/731).

Kara çul giymek: Bir felaket dolayısıyla siyah örtü bağlanmak, siyah elbise giymek; yas tutmak; bir durumdan dolayı pek çok üzülmek (ÖAA: II/910; EKE: II/292; İP: II/545; AP: 525; MES: II/734; MAT: 167). Ayrica bk. Kara(lar) giymek.

Hattı geldi gitdi ey dil hüsn-i bi-hemtâ-yı dôst

Kara çul geydi anuñçün 'ârız-ı zîbâ-yı dôst (M.34)

Kara gönüllü: Acımasız, acı duymayan, acıya duyarsız (EKE: II/292).

Hey ne kara göñüllü o zülfü̈ñ dil-i 'uşşâk

Bir târına asılsa kılı kımramaz aslâ (G.27/2)

Kara sürmek: Karalamak; suçlamak, suçlu ilan etmek (EKE: II/293; MES: II/733).

Mâhuñ yüzine kara sürüp gezdürür felek

Öykündi var ise yine yâruñ yanagına (G.426/3)

Kara yağız (G.103/3, G.361/2): Karaya yakın, esmer (MES: II/733).

Kara yazılı (G.398/4, M.310/2): Bedbaht, talihsiz, bahtı kara (EKE: II/293; MAT: 167).

Kara yüzlü (G.524/1): Utanç verici işler yapan, lekeli (EKE: II/293; AP: 526; MES: II/734).

Ruh-ı dil-dârı kabz itmiş bir iki kara yüzlüler

Kiminüñ adı kâküldür kiminüñ hatt u hâl olmış (G.231/3)

Kara(lar) giymek (G.383/5): Bir felaket dolayisiyla siyah örtü bağlanmak, siyah elbise giymek; yas tutmak; bir durumdan dolayı pek çok üzülmek (ÖAA: II/910; EKE: II/292, 294; İP: II/545; AP: 525; MES: II/734; MAT: 167). Ayrıca bk. Kara çul giymek. 
Karş1 durmak (G.237/2, G.419/3, G.565/2): Güçlüye boyun eğmemek, direnmek (ÖAA: II/913; EKE: II/295; İP: II/550; AP: 529; MES: II/741; MAT: 168).

Karşı gelmek (G.217/2, M.373, M.389/1): Boyun eğmeyip başkaldırmak, kafa tutmak; dışarıdan gelen kimseyi karşılamaya gitmek, istikbal etmek (ÖAA: II/914; EKE: II/295; İP: II/550; AP: 529; MES: II/741; MAT: 168).

Karşı koymak (G.457/5, G.546/3): Sert bir davranışla ya da güç kullanarak engel olmaya çalışmak, diklenmek, boyun eğmemek (ÖAA: II/914; EKE: II/295; İP: II/550; AP: 529; MES: II/742).

Kaş çatmak (G.454/1): Kızgınlığını, öfkesini kaşlarını birbirine yaklaştırarak belli etmek; sinirlenmek (EKE: II/296; IP: II/551; AP: 530; MES: II/743-744).

Kazaya uğramak (M.164/1): Umulmadık olumsuz bir durumla karşılaşmak.

Kef geçmek: Hayrete düşmek, kendinden geçmek; mala, mülke aşırı derecede düşkün olmak (MAT: 170).

Emrî gamzeñ tîri üzre cân virüben kef geçer

Ya'nî sen kaşı kemânuñ kulı kurbânı geçer (G.195/5)

Kellesi/kafası kızmak (G.40/1): Öfkelenmek, kızmak (ÖAA: II/898; EKE: II/299; IP: II/525; AP: 504; MES: II/702).

Kendi gözündeki çöpü görmek: Kendi hatasını görmek, kendine bakmak.

Nergis çü ta'n idemez aña olmasun melûl

Kendü gözindeki çöpi görsün efendi ol (M.299)

Kendinden geçmek (G.561/3): Bilincini yitirmek, bayılmak; bir şey karşısında çoşkuya kapılmak, aşırı duygulanmak; uykuya dalmak; nefsini öldürmek (ÖAA: II/921; EKE: II/301; İP: II/562; AP: 540; MES: II/760-761; MAT: 172).

Kendine yon(t)mak: Eline geçen fırsattan yararlanarak hep kendi çıkarı için çalışmak ve kazanç sağlamak (ÖAA: II/971; EKE: II/301; IP: II/563; AP: 541; MES: II/762; MAT: 173). 
Kendüye yondugıçün ol kodılar taşında

Kasr-ı 'ışkuñ içine koymadılar kûhkeni (M.490/2)

Kendini bilmemek: Aklı başında olmamak; bilinci yerinde olmamak; sarhoş olmak (EKE: II/302).

Ahter-i burc-ı vefâyam ben didükde Emriyâ

Mest idi bilmezdi kendün ol cemâli âfitâb (G.40/5)

Kendini bilmez (G.77/5): Aklı başında olmayan; nerede, nasıl davranacağını, ne söyleyeceğini bilmeyen; sarhoş.

Kendini yüksekte tutmak (M.255): Kendini büyük görmek, büyüklenmek (EKE: II/304).

Kıl yarmak: Çok titizlik göstermek, titiz ve ayrıntılı bir biçimde incelemek (ÖAA: II/928; EKE: II/306; IP: II/571; AP: 549; MES: II/776; MAT: 176). Ayrıca bk. Kılı bin yarmak.

Zülfden yüzüñe gelmiş ser-i mûdur dehenün

Kıl yarar sözde anuñçün leb-i şekker-şikenüñ (G.271/1)

Kılı bin/kırk yarmak: Çok titizlik göstermek, titiz ve ayrıntılı bir biçimde incelemek (ÖAA: II/928; EKE: II/307; İP: II/571; AP: 549; MES: II/776; MAT: 176). Ayrıca bk. Kıl yarmak.

Bir kılı biñ yardı tab'-ı mû-şikâfum Emriyâ

Bagladı ol mû-miyân vasfinda bir ince hayâl (G.302/5)

Kılı kımramamak: Bir olay karşısında ilgisiz kalmak, aldırış etmemek (ÖAA: II/928; EKE: II/307; İP: II/571; AP: 549; MES: II/776).

Hey ne kara göñüllü o zülfü̈n dil-i 'uşşâk

Bir târına asılsa kılı kımramaz aslâ (G.27/2)

Kılını kıpırdatmamak: bk. Kılı kımramamak.

Kılıç bıçak olmak: Birbiriyle kılıç çekerek kavga etmek, savaşmak (EKE: II/308).

Gamzeler birle o kâtil pür yarag olmış yine

Ehl-i 'ışk ile meded kılıç bıçag olmış yine (G.439/1) 
Kılıç (şemşîr, tîg) çekmek (Muh.1/II, G.6/2, G.74/4, G.430/4, G.441/1, G.477/4, M.225): Saldırıya geçmek ya da selam durmak amacıyla kılıcı kınından çıkarmak (EKE: II/308; IP: II/572; AP: 549; MES: II/776).

Kılıç tartmak: Birisini öldürmek için kılıca sarılmak; kılıcını hazırlamak; kılıcını bir şeye, birine karşı hazır etmek.

Fitnenüñ atılmış okı gamze-i meftûnıdur

Câna tartılmış kılıcı ebrû-yı mevzûnıdur (M.85/1)

Kılıçtan geçmek/geçirmek (G.327/4, G.542/3): Çok sayıda insanı k1lıç kullanarak öldürmek (ÖAA: II/927; EKE: II/308; IP: II/572; AP: 549; MES: II/776; MAT: 176).

Kıpkızıl divane: Kaçkın, zırdeli (ÖAA: II/933; EKE: II/308-309; IP: II/580; AP: 556; MES: II/788; MAT: 177).

Gonca la'l-i yârun olmış kıpkızıl dî̀ânesi

Âb-ı şebnem sanma kim akar dehânından lü'âb (G.36/4)

Kıyamet kopmak (G.61/2): Kıyamet günü gelmek; bir yerde çok gürültü ve patırtı olmak (EKE: II/310-311; IIP: II/578; AP: 555; MES: II/786).

Kıyamete kalmak: Bir işin veya sorunun çözümü Allah'a kalmak; çözüm imkânı bulunmamak (EKE: II/311; İP: II/578; AP: 554; MES: II/786).

İrdi ecel el irmedi sen serv-kâmete

'Ömrüm n'idem ki kaldı bu hasret kıyâmete (G.509/1)

Koynuna girmek (G.178/1, M.138): Biriyle gizlice yatmak (IP: II/590; AP: 564; MES: II/803).

Koynunda yılan beslemek (G.175/5): Bir yakınından, iyilik yaptığı birinden kötülük görmek (İP: II/590; AP: 564; MES: II/803).

Kök salmak (G.275/2): Sorunlar büyümek, yayılmak, köklenmek; bir yere iyice yerleşmek (ÖAA: II/938; EKE: II/315; IIP: II/592; AP: 565; MES: II/804).

Köküne kibrit suyu dökmek/Kökünü kurutmak: bk. Kökünü güne göstermek/sermek. 
Kökünü güne göstermek/sermek (G.134/3): Bir daha oluşamayacak, ortaya çıkamayacak bir biçimde yok etmek (ÖAA: II/938; EKE: II/315; IIP: II/592; AP: 565; MES: II/805).

Serv öykünürse yâra leb-i cûy-bârda

Ey bâd anuñ kökin güne göster kenârda (G.501/1)

Kul etmek (G.554/1): Birini kendine mecbur bırakıp tâbi kılmak (EKE: II/317).

Kul olmak (G.14/1, G.345/5, G.463/1): Birine karşı büyük saygı ve sevgi beslemek; ona karşı her fedakârlığı yapmaya hazır olmak; bağlanmak (EKE: II/317; IP: II/597; AP: 574; MES: II/814).

Kulağa düşmek (ağızdan): Herkes tarafından duyulmak, sır ortaya çıkmak.

Dimiş dehânı vasfin gonca çemende verde

Sırr-ı nihânum ey dil femden kulaga düşmiş (G.237/4)

Kulağına çalmak (G.569/2): Kulağına gelmek, duymak.

Kulağına değmek/değmemek: Kulağına gelmek, duymak; kulağına gelmemek, duymamak (EKE: II/318; MES: II/815).

Figânum gökde meh deryâda mâhî gûşına irdi

'Aceb bilsem niçün ey gül senüñ kulagına degmez (G.212/4)

Kulağına (gûşuna) koymak (G.151/1, G.173/4, G.416/3, G.426/5): Sırası gelince hatırlaması için birine bir şey söylemek; iyice anlatmak, telkinde bulunmak (ÖAA: II/942; EKE: II/319; IP: II/598; AP: 572; MES: II/816; MAT: 183).

Gül 'andelîbe karşu yüzin dürdi Emriyâa

Kim bildi jâleler ne koyupdur kulagına (G.513/6)

Kulağına parmak tıkamak (G.34/5): Kulağını kapatmak, duymak istememek, duymamak.

Kulağını çekmek (M.454/1): Ceza olarak kulağını tutup bükerek çekmek; uyarmak için hafif bir ceza vermek; bir daha yapmamasını sağlayacak yolda ögütleyip darılmak (ÖAA: II/943; EKE: II/319; IP: II/599; AP: 572; MES: II/817; MAT: 184).

Kulağını yemek: Sesiyle rahatsızlık vermek, sesiyle bıktırmak. 
Dehânina alup gül-bergi bîhûde figân itmez

Yüzüñ hecrinde nâleyle kulagın yir gülüñ bülbül (M.288/2)

Kulağını açmak (G.299/3): Söylenene dikkat etmek, dikkatle dinlemek (ÖAA: II/943; EKE: II/319; İP: II/599; AP: 572; MES: II/817).

Kulak çekmek: Çok beğenmek (EKE: II/320).

Gûşvâruñ k'oldı dürr-i lutf ile âreste

Gördi çün lutf-ı bînâgûşuñ senüñ çekdi kulak (M.248/3)

Kulak urmak (M.353): Kulak tutmak, dinlemek (EKE: II/321).

Kulaktan âşık etmek (G.123/5): Anlattıklarıyla birine âşık olmasını sağlamak.

İdüp ta' rîf gül-i rûy-ı nigârı

Kulakdan 'âşık itmişdür hezârı (M.461/1)

Kulaktan âşık olmak (Müst.1/3): Yalnızca kendisine anlatılanlarla görmeden birine karşı sevgi beslemek (ÖAA: II/944; EKE: II/321; IP: II/600; AP: 573; MES: II/819; MAT: 184).

Görür hüsn ehlinüñ rûyın göñül gayriya meyl itmez Kulakdan 'âşık olmışdur gülü̈ñ bülbül hezârına (G.479/4)

Kulpu elinde kalmak: Talihsiz olmak; bahtı müsaade etmemek.

Her neye ursam elüm kulpı kalur destümde

Gördi bir şahs didi bezmde kaldurma sebû (G.419/4)

Kurban olmak (G.195/3, M.283/1): Uğruna 1ztırap, üzüntü, sıkıntı çekmek; ölmek; kendini feda etmek (EKE: II/322-323; İP: II/602; AP: 575; MES: II/821).

Kuru sevda: Karşılıksız aşk (EKE: II/324; MES: II/825).

Dîde sarf itdi yaşum nakdin kurı sevdâlara

Zülfi devrinde dil-i miskîn benüm nem n'eyledi (G.551/4)

Kuyruğuna basmak (G.269/1): Birini inciterek onun saldırıda bulunmasına sebep olmak (ÖAA: II/948; EKE: II/326; İP: II/607; AP: 579; MES: II/829; MAT: 189). 
Kül etmek/eylemek (G.250/2, G.298/2, M.218/4, M.277/1): Yakıp kavurmak; birinin varını yoğunu yok etmek; parasını pulunu yemek (EKE: II/327; IP: II/611; AP: 581; MES: II/832).

Kül olmak (G.139/4, G.571/7): Tamamen yanmak; varını yoğunu kaybetmek, elde bir şey kalmamak; bir acı dolayısıyla pek çok üzüntü çekmek (ÖAA: II/951; EKE: II/327; İP: II/611; AP: 582; MES: II/833; MAT: 190).

Kül ufak etmek/olmak: Çok küçük parçalara ayırmak/ayrılmak (AP: 582; MES: II/833).

Eylemişdi âteş-i mihrüñ yakup eczâmı kül Hurd idüp seng-i cefâlarla sen itdüñ kül ufak (G.250/2)

Külahını havaya atmak: Mutluluktan havalara uçmak, çok sevinmek (ÖAA: II/950; EKE: II/328; AP: 581; MES: II/834; MAT: 190).

Yüz sürdi meh ü mihr o şehün hâk-i derine

Her birisi atdı külehin çarh-ı berîne (G.486/1)

Malum olmak (G.479/3, G.546/4, M.307/1): İçine doğmak; olacağ1 önceden kestirmek, sezmek (ÖAA: II/870; İP: II/629; AP: 595; MES: II/856-857).

Mat etmek (G.68/2, G.68/7): Satranç oyununda yenmek; bir tartışma sonunda karşısındakini cevap veremez duruma düşürmek; bozmak; yenmek (ÖAA: II/962; EKE: II/333; İP: II/633; AP: 600; MES: II/862; MAT: 192).

Mata yakın olmak (G.371/5): Yenilmek üzere olmak.

Matem etmek (M.381/2): Çok acı çekmek, yas tutmak; çekilen acı ve üzüntüyü hareketleriyle belli etmek (ÖAA: II/1109; EKE: II/420; IP: II/902; AP: 799; MES: II/862; MAT: 192).

Matem tutmak (G.88/1): Çok acı çekmek, yas tutmak; çekilen acı ve üzüntüyü hareketleriyle belli etmek (ÖAA: II/1109; EKE: II/420; IP: II/902; AP: 799; MES: II/862; MAT: 192).

Mekân tutmak (G.455/5, G.559/3): Bir yere yerleşmek (AP: 602; MES: II/865-866). 
Meydana/ortaya çıkmak (G.543/1): Belli olmak, belirmek, anlaşılmak; ortaya çıkmak; ortada kendini göstermek (ÖAA: II/966; EKE: II/335; IP: II/682; AP: 605; MES: II/873; MAT: 193).

Mil çekmek (G.373/2): Birinin gözlerini kızgın şişle kör etmek (IP: II/643; MES: II/877).

Tîrüñi gördi ki zahmuñ gözle yir anuñ fitîl

Dîdesine mîl çekdi ey kemân-ebrû hemîn (G.377/3)

Mim koymak: Unutulmaması için işaret koymak; önemli bularak üstünde 1srarla durmak (ÖAA: II/968; EKE: II/336; İP: II/644; AP: 607; MES: II/877).

Ol leb üzre gaybdan bir mîm komışlar fem degül

Ruhdan la'li mukaddem oldugin eyler beyân (G.363/3)

Minnet etmek (G.73/1): Yaltaklanmak, boyun eğip yalvarmak (EKE: II/336; IP: II/644).

Murat almak/almamak (G.73/2): İsteğine, arzusuna, dileğine kavuşmak/ kavuşamamak (EKE: II/338; IP: II/648; AP: 609; MES: II/882).

Çihresi zerd içi pür-hûndur benüm gibi meger

Almamışdur bâg-ı deorândan gül-i ra'nâ murâd (G.73/4)

Müjde vermek (G.467/3): Bir kimseye sevindirici, mutlu bir haberi ulaştırmak (İP: II/649; MES: II/884).

Nakış geçmek: Oyun etmek, kurnazlıkla birini aldatmak, hile yapmak (MAT: 196).

Bir hayâl ignesidür gamze-i dil-dûz-ı nigâr

Gözi anuñla dil-i 'âşıka çok nakş geçer (G.132/3)

Nal kesmek (G.130/4, G.301/5, G.302/3, G.312/3, M.243): Göğsünü nal şeklinde dağlamak (MAT: 198).

Dâg yakmış 'ışkuña gün na'l kesmiş mâh-ı nev

Tekye-i 'ş̧kuñda mihr ü meh iki abdâldür (G.103/2)

Nâra yakmak: Bir kimseye ve kendine zarar vermek, zararı dokunmak (EKE: II/340; IIP: II/657; AP: 614; MES: II/891). 
Beni nâra yakup her katre eşküm dâne-i nâr it

Dir isem gevher-efşân la'lüñe yâkût-ı rümmânî (G.540/3)

Nazar dokundurmak: Göz değdirmek.

Hâl-i ruhsârı karardugı bu kim

Merdüm-i dîde tokındurdı nazar (M.144/2)

Nazına katlanmak (G.202/5): İstenen her şeyi şartlar ne olursa olsun yapmak veya yerine getirmek (IP: II/659).

Ne çare (G.55/4, G.79/4, G.278/4): Elden bir şey gelmez, çaresi yok (ÖAA: II/973; İP: II/660; AP: 616; MES: II/894; MAT: 197).

Ne (kara) günlere kaldık (G.511/5): Eski düzenler, yöntemler değşti; şimdi çok kötü bir düzen ve yöntem var; niçin böyle durumlara düştük? (ÖAA: II/976; EKE: II/341; IP: II/661; AP: 618; MAT: 198;).

Ne yüzle (G.29/4, M.292/2): Hiç utanıp sıkılmadan (EKE: II/342; AP: 623; MES: II/901).

Necat bulmak (G.58/1, G.60/4): Kurtulmak, özgür kalmak (IPP: II/664; MES: II/901).

Nefese uğramak: Büyüye maruz kalmak.

Sâgar-ı meyde şi̧̧üp çatladı bir demde habâb

Lebüñ içün nefese ugradı var ise şarâb (G.53/1)

Nevbet/nöbet beklemek/tutmak: Bir yeri veya bir kimseyi korumak amacıyla gözetlemek, bulunduğu yerden belli bir süre için ayrilmamak; sıra ile beklemek (ÖAA: II/981; IIP: II/670; MES: II/909).

Şehr-i cânı seng-i mihnetle gam itmişdür hisâr

Nâlemüzle biz beden burcinda nevbet beklerüz (G.210/2)

Nihayet bulmak (M.164/4): Sona ermek, sonuçlanmak; tükenmek, bitmek (IP: II/667; MES: II/906).

Nur inmek (G.111/2): Kutsal bir yere gökten İlâhî bir ışık yağmak (EKE: II/344; IIP: II/671; MES: II/910). 
Ocağına su koymak (G.260/4, G.513/4): Ocağını söndürmek, evini barkını yıkmak, çoluk çocuğunu yok etmek (EKE: II/346; MES: II/915; MAT: 200).

Âteş-i hecr-i ruhuñla beni yandurma iñen

Hazer it ocaguña dîde-i 'âşık su koyar (G.135/3)

Olur olmaz (G.570/5): Sıradan; kim olduğu, niteliği belirsiz; önemsiz, yersiz; iyi mi kötü mü olduğuna bakılmaksızın seçilen şey (ÖAA: II/986; EKE: II/348-349; İP: II/677; AP: 631; MES: II/919; MAT: 202).

Ortaya almak (G.69/1-5): Her tarafını çevirmek, kuşatmak (İP: II/681).

Oyun gözetmek: Birini oyuna getirmek için fırsat kollamak.

Başuñı top gibi çalmaga oyun gözedür

Gâfil olma ki hilâl almış ele çevgânı (G.531/3)

Oyun oynamak (G.409/3): Birini aldatmak, tuzağa düşürmek (ÖAA: II/991; EKE: II/350; IP: II/685; AP: 638; MES: II/929; MAT: 203).

Ölüsü yasına (şivenine) değmemek: Değer vermemek; ölümü için üzülmemek.

Gül-i pejmürde içün itmedi bülbül mâtem

Bildi anuñ ölüsi degmez imiş şîvenine (M.381/2)

Ömrü oldukça (G.328/5, M.288/1): Yaşadıkça, yaşadığı sürece (İP: II/693; MES: II/938).

Ön vermemek (G.458/5): Yol vermemek; önünü, yolunu kesmek.

Önayak olmak (G.31/3): Topluca yapilan ya da yapılacak olan bir işin başlatıcısı ve yol göstericisi durumunda olmak; bir işe ilkin başlayıp herkesi arkasından sürüklemek (ÖAA: II/996; EKE: II/353; İP: II/696; AP: 643; MES: II/939; MAT: 206).

Önüne düşmek (G.332/6): Birinin önünden gitmek; yol göstermek, rehberlik etmek (ÖAA: II/996; EKE: II/353; IP: II/695; AP: 644; MAT: 206). 
Öpüp başına komak (G.4/5): Bir nimeti veya kutsal sayılan bir varlığ1 saygiyla el üstünde tutmak; bir şeyi memnunlukla karşılamak, saygiyla karşılamak, lütuf saymak (ÖAA: II/998; EKE: II/353-354; IIP: II/697; AP: 645; MES: II/941; MAT: 207).

Pahası bir pul (G.281/1): Hiçbir değeri bulunmamak, çok değersiz olmak.

Egerçi şem' yalin yüzlü bir güzel kuldur

Saña mı beñzer ol anuñ bahâsı bir puldur (M.203)

Pahasına akçe saymak (M.403): Para ödemek; satın almak.

Gülşende her gülüñ yapışursin yakasına

Ey jâle yohsa akça mı sayduñ bahâsına (G.428/1)

Pamuk (penbe) atmak (G.539/5): Yay ve tokmakla pamuğu ditmek (İP: II/704; MES: II/950).

Parmağı ağzında kalmak: bk. Ağzına parmak sokmak.

Parmağına değmemek (birinin) (G.211/1, G.211/5, G.212/1): Değerli olmamak; birinden çok değersiz olmak.

Parmak dişlemek (M.284/1): Pek çok şaşmak, hayret etmek, hayretler içinde kalmak (ÖAA: II/1006; IP: II/709; AP: 656; MES: II/957; MAT: 210). Ayrica bk. Parmak ısırmak.

Degül lâle letâfet gülşeninde gonca-i zanbak

Görince bîn̂े-i sîmîn-i yârı dişlemiş barmak (M.246/1)

Parmak 1sırmak: Büyük bir şaşkınlık içinde olmak, hayrette kalmak (ÖAA: II/1006; EKE: II/357; IP: II/711; AP: 657; MES: II/958; MAT: 210). Ayrıca bk. Parmak dişlemek.

Göricek kaşuñ hamın barmak ısırdı mâh-ı nev

Ey hilâl-ebrû şafak sanma bulaşdı kan aña (G.14/4)

Parmakla gösterilmek (G.28/3, G.546/2): Az bulunmak, değerli görülmek; seçkin veya ünlü olmak (ÖAA: II/1007; EKE: II/357; İP: II/711; AP: 657; MES: II/959).

Pazar(l1k) etmek (G.244/3, G.501/3, M.177/1, M.184/1): Bir şeyin fiyatı üzerinde karşılıklı çekişmek; herhangi bir konuda anlaşmak için görüşme yapmak (IPP: II/715; AP: 660; MES: II/964). 
Pençesini burmak: Kolunu bükmek, yenmek (EKE: II/358; MAT: 211).

Gâlibâ halkuñ budur devrildi gün didükleri

Şems-i 'asruñ pençesin burduñ yed-i beyzâ ile (G.448/2)

Perde inmek (gözüne) (M.198): Gözde katarakt oluşmak; gizlemek, örtmek (EKE: II/224; IIP: II/716; AP: 661-662; MES: II/965).

Peşkeş kılmak/çekmek (M.151/2): Bir kimseye yaranmak için kendisinin ya da başkasının malını armağan olarak sunmak; verilmemesi gereken bir şeyi uygunsuz bir amaçla veya yersiz olarak vermek (ÖAA: II/1011; EKE: II/359; IPP: II/719; AP: 664; MES: II/968; MAT: 211).

Pişmiş aşa soğuk su katmak: bk. Pişmiş aşı bozmak.

Pişmiş aşı bozmak: Yoluna girmiş olan ya da sonuçlanmak üzere olan bir işi bozacak davranışta bulunmak; yürümekte olan bir işi engellemek (ÖAA: II/1013; EKE: II/360; IP: II/721; AP: 666; MES: II/972).

Tenümde yara bitmişken yine üstine zahm urdı

Gelüp bişmiş aşı bozdı ne çâre tîr-i bürrânuñ (G.278/4)

Ramak kaldı (G.256/5): Çok az kaldı, az kalsın olacaktı (ÖAA: II/1017; EKE: II/362; İP: II/728; AP: 673; MES: II/982; MAT: 213).

Reng eylemek (G.27/5): Hile yapmak, oyun etmek, aldatmak (EKE: II/362).

Reng geçmek (M.289/4): Hile yapmak, oyun etmek, kurnazlık ile birini aldatmak (MAT: 213).

Yaşumı bir reng ile ol la'l hûnîn eylemiş

Reng geçmiş aña gerçi lîk rengîn eylemiş (G.225/1)

Renk almak (G.76/3, G.290/2, M.117/1): Değişik ve yeni bir renk kazanmak; yeniden canlanmak; niteliği değişmek (İP: II/730; AP: 674; MES: II/984).

Renk vermek (G.94/5, G.493/2, M.37/2, M.395/3): Canlılık veya değişiklik kazandırmak; duygularını, düşüncelerini veya başka 
bir durumunu belli etmek; aldatmak (EKE: II/362; İP: II/731; AP: 674; MAT: 214).

Rıza göstermek (G.21/3): Razı olmak, uygun bulmak, karşı çıkmamak (IIP: II/732; MES: II/986).

Rüyasında (ancak) görmek (G.41/3): Bir şeyin gerçekleşmesine imkân olmamak.

Sabaha diri çıkmak: Düşüne düşüne, hiç uyumadan sabahı etmek; uyumayarak sabahlamak (MES: II/992).

Emriyâ gice sabâha diri çıdı encüm

Göz yumup uyumadı nâle-i şeb-gîrüñden (G.381/5)

Saf bağlamak (G.154/3, G.448/4): Saf saf durmak, sıra sıra olmak; savaşa hazır olmak üzere gemiler sıraya dizilmek (EKE: II/365; IIP: II/739; MES: II/996).

Selam vermek (M.342/1): Selamlamak, esenlik dilemek; başını sağ ve sol omuzlarına çevirerek namazı bitirmek (ÖAA: II/1030; İP: II/753; AP: 689; MES: II/1012; MAT: 218).

Serkeşlik etmek (G.289/4): Baş kaldırmak, buyruk dinlememek, isyan etmek; öncülük etmek, ilk adımı atmak; halk oyunlarında halayın başında oyunu yönetmek (ÖAA: II/617; EKE: II/52; IP: II/151; AP: 144; MES: I/174; MAT: 59). Ayrica bk. Baş çekmek.

Sesini kesmek (G.356/3): Konuşmamak, söylemekte iken susmak; bir kişiyi artık söyletmemek (ÖAA: II/1033; EKE: II/371; İP: II/758; AP: 693; MES: II/1018; MAT: 219).

Sevdasına düşmek (M.236/1): Gerçekleştirmeyi çok istediği bir işi başarma çabası içinde olmak; bir şeyi amaçlamak, başarmaya çalışmak; âşık olmak (ÖAA: II/1033; EKE: II/371; İP: II/759; AP: 694; MES: II/1018; MAT: 219).

Sevdaya salmak (M.163/2, G.319/6): Âşık etmek (EKE: II/371).

Silip süpürmek (M.256): Evi, ortalığ1 temizlemek; ne var ne yoksa hepsini yemek; ne var ne yoksa hepsini alıp götürmek (ÖAA: II/1038; EKE: II/373; IP: II/769; AP: 701; MES: II/1030; MAT: 219). 
Sineye çekmek (G.12/1, G.127/3, G.346/4, M.262/2): Kötü bir davranış, söz veya olaya ister istemez katlanmak; göğsüne yaslamak, kucaklamak (ÖAA: II/1038; EKE: II/374; İP: II/769; AP: 701; MES: II/1031; MAT: 220).

Siper almak (G.91/3): Bir yeri veya şeyi siper olarak kullanarak gizlenmek (İP: II/771).

Söz açmak (G.198/3, G.397/6): Bir konuya giriş yapmak; bir konu veya kişi üzerinde konuşmaya başlamak (ÖAA: II/1043; EKE: II/376-377; IP: II/780; AP: 708; MES: II/1042; MAT: 220-221).

Söz/laf atmak (M.74/2): Sözle sataşmak; birisine, dokunacak uygunsuz söz söyleyip işittirmek (ÖAA: II/952; EKE: II/377; İP: II/616; AP: 709; MES: II/1043; MAT: 221).

Söz atar nâvek-i kâtil müje-i cânâna

Okçılar anuñ içün agzını yurlar kana (G.462/1)

Söz değmemek: Söz düşmemek.

Dime 'uş̧̧̂k içre yâra bir sözüñe degmedük

Ey rakîb erbâb-ı dil yanında söz degmez saña (G.13/5)

Söz kaçırmak: Sözün nereye gittiğini bilmeden söylemek; sözünü bilmemek.

Şeker dimiş leb-i şîrîn-i yâra söz kaçırmışdur

Sözinüñ kanda gitdügini bilmez tûti-i gûyâ (G.26/4)

Sözüne değmek (G.13/5): Birinden ya da bir şeyden söz etmek; biri üzerine konuşmak.

Sözünün nereye gittiğini bilmemek (G.26/4): Sonunu düşünmeden konuşmak; söylediklerinin neler getireceğini bilmeden söylemek.

Su basmak (M.78/1): Sular altında kalmak, her yanı suyla dolmak (İP: II/786; MES: II/1051).

Su gibi ezberlemek (M.145): Yanlışsız ve hızlı okuyabilecek kadar ezberlemek (ÖAA: II/1048; EKE: II/380; IIP: II/787; AP: 715; MES: II/1052). 
Su gibi (revân) okumak: Bir yazıyı veya kitabı hızlı, kolay ve yanlışsız okumak (ÖAA: II/1048; IP: II/787; AP: 715; MES: II/1052).

Su gibi sâfî dilinde her zamân okur revân

Eylemiş bu matla'ı ey sebz-hatt ezber çemen (K.2/18)

Suçunu bağışlamak (G.201/5): Bir kimseye işlediği suçun cezasını vermemek, suçunu affetmek (EKE: II/381; IP: II/791; MES: II/1054).

Şişe çekmek (G.36/3): Vücut ağrılarını dindirmek amacıyla içinde alev yakılarak havası seyreltilen özel bir şişeyi veya bardağ sirta uygulamak (ÖAA: II/1060; İP: II/809; AP: 729-730; MES: II/1078; MAT: 228).

Şişip kabarmak: Gururlanmak, böbürlenmek.

Habâb-ı mey niçün şişüp kabarmasuñ ki bezmüñde İder bâd-ı hevâdan günde bir la'l efseri peydâ (G.26/3)

Şöhret bulmak (G.28/3): Meşhur olmak, üne kavuşmak (İP: II/809; MES: II/1078).

Şöyle ki/kim (G.1/4, G.16/3, G.26/5, G.33/2, G.146/2, G.151/4, G.172/5): Açıklamak gerekirse, açıklayayım (ÖAA: II/1061; AP: 730; MES: II/1079).

Tâkat getirmek/getirmemek (G.355/1): Ac1 ve sıkıntılara dayanmak, katlanmak, tahammül etmek/etmemek (EKE: II/387; IP: II/813; MES: II/1087).

Gördi tâbı hüsnüme tâkat getürmez hâss u 'âm

Sâye saldı ilticâ içün bu zülf-i 'anberîn (G.371/4)

Tâkati tâk olmak: Dayanamamak, gücü yeterli olmamak (İP: II/813; MES: II/1087). Ayrıca bk. Tâkati yetmemek.

Tâk oldı tâkatüm gam-ı ebrû-yı yâr ile

Döndi harâb manzaraya dîde hâbsuz (G.203/2)

Tâkati yetmemek (G.459/1): Dayanamamak, gücü yeterli olmamak (İP: II/813). Ayrıca bk. Tâkati tâk olmak. 
Taş altında kalsın (M.377/2): “Ölsün, yok olsun" şeklinde bir beddua sözü.

Taş bağırlı (G.153/4): Katı yürekli, hiç acıması olmayan, duygusuz (ÖAA: II/915; EKE: II/230; İP: II/821; AP: 738; MES: II/1095). Ayrıca bk. Bağrı katı, Taş yürekli/kalpli.

Taş üstünde taş kalmamak: Tümüyle yıkılıp yerle bir olmak (EKE: II/391).

Emrî binâ-yı 'ışka halel ire korkarm

Taş üzre taşı kalmadı Ferhâddan berî (G.520/5)

Taş yürekli/kalpli (G.558/3): Acıklı şeylerden üzüntü duymayan, duygusuz, katı yürekli (ÖAA: II/915; EKE: II/391; IPP: II/821; AP: 738; MES: II/1095). Ayrıca bk. Bağrı katı, Taş bağırlı.

Taşa tutmak (G.435/1): Üst üste taş atmak, aralıksız taşlamak; sürekli eleştirmek (ÖAA: II/1066; EKE: II/392; IP: II/820; AP: 737; MES: II/1095; MAT: 229).

Ter düşmek/düşürmek (G.45/1, G.288/4, M.75, M.465): Küsmek, gücenmek, öfkelenmek; sıkılmak, kıskanmak, aciz bırakmak; sıkıntı verip terletmek (MAT: 232; Yılmaz 2009: 155-170).

Kendüyi rûy-ı 'arak-nâküñe beñzetdügiçün

Ter düşüp jâle yapışdı yüzine verd-i terïñ (M.263/3)

Tırnağına değmemek (G.212/1): Kıymet bakımından çok daha aşağı olmak (İP: II/840; AP: 751).

Toprağa (hâke) düşmek (T.1/4, G.235/5): Vefat ederek mezara konulmak, ölmek ve defnedilmek (EKE: II/398; IIP: II/844; MES: II/1125).

Egerçi girye cenginde düşüpdür topraga çogı

Sipâh-ı eşk-i çeşmüm yine ey şeh b̂̀-nihâyetdür (G.158/4)

Toprak (hâk) etmek/eylemek/kılmak (G.130/2, G.403/1, G.518/3, M.370/1): Öldürmek.

Nâle eylerken lebüñçün gam beni hâk eylese Ney-şeker ola türâbumda biten her bir nebât (G.58/2) 
Toprak (gubâr, hâk) olmak (G.30/1, G.438/5, G.459/5, M.107/2, M.255/1, M.362/3, M.422): Mezara gömülmek, ölmek; öldükten sonra bedeni çürüyüp toprağa karışmak (İP: II/844; AP: 754; MES: II/1125).

Tuzağa düşmek (G.237/5): Birilerince hazırlanan hileli, kötü bir duruma uğramak (ÖAA: II/1079; EKE: II/401; İP: II/849; AP: 758; MES: II/1131).

Uykuya varmak (G.563/5): Yavaş yavaş uykuya dalmak; sakin, sessiz ve hareketsiz bir ortam oluşturmak (EKE: II/405; IP: II/862; AP: 768; MES: II/1146).

Üstünde kalmak (G.277/2): Bir mal veya iş açık artırma yoluyla kendisinde kalmak; yerine getirememek, borçlu kalmak; suçlanmak (ÖAA: II/1089; EKE: II/406; İP: II/868; AP: 773; MES: II/1154).

Üstünde/üstüne titremek (G.328/3): Çok sevdiği bir şeye veya kimseye zarar gelmemesini istemek, onu koruma altına almak (ÖAA: II/1091; EKE: II/407-408; İP: II/870; AP: 775; MES: II/1157; MAT: 238).

Üstüne gelmek (G.375/2, G.427/2): Üstüne varmak, saldırmak; bir şey yapılırken veya konuşulurken çıkagelmek; bir şeyi yapması için zorlamak (ÖAA: II/1091; EKE: II/407; İP: II/869; AP: 774775; MES: II/1156; MAT: 238).

Üstüne kalkmak: Üzerine gitmek.

Kalkmışdı hat-ı sebz ile anuñ üstine çok

Yüridi üstine ol serv-i revân yatdı çemen (M.347/2)

Üstüne varmak (Müst.1/2): Bir şeyi baskı yaparak istemek, 1srarc1 olmak; üstüne doğru gitmek ya da saldırmak; kadın, evli bir kadının kocasılla evlenmek (ÖAA: II/1092; EKE: II/408; İP: II/871; AP: 776; MES: II/1157).

Üstüne yürümek (M.347/2): Korkutmak, yıldırmak amacıyla saldıracakmış gibi yapmak; üstüne doğru saldırırcasına gitmek (ÖAA: II/1092; EKE: II/408; İP: II/871; AP: 777; MES: II/1158; MAT: 239). 
Vücuda gelmek (G.390/2): Ortaya çıkmak, oluşmak, meydana gelmek (IIP: II/883; MES: II/1172).

Vücuda getirmek (G.407/2): Ortaya koymak, meydana getirmek, var etmek (EKE: II/410; İP: II/883; MES: II/1172).

Yaban oğlanı: Gelişigüzel yetişmiş, eğitilmemiş genç (Dilçin 1983: 229).

Tekye-i 'ışkda Mecnûn nice pîrem diye kim

Olmamışdur o yaban oglanı dahi 'âkil (G.304/3)

Yabana atmak (G.223/1, G.305/2): Değer vermemek, önemsiz görmek, itibar etmemek (ÖAA: II/1099; EKE: II/411; İP: II/886; AP: 787; MES: II/1174; MAT: 241).

Tîrüñi atma yabana baña at didüm idi

Nesnemüz yok didi ol şûh yabana atacak (G.256/4)

Yabana gitmek: Boşa harcanmak (AP: 787; MES: II/1174).

O derde dökilen kanum yabana gitdi sanurdum

Heder olmamış ey Emrî anı ol hâk-i der sormış (G.241/5)

Yaka yırtmak (G.215/5, G.318/2, G.450/4, G.462/3, G.540/1): Büyük bir üzüntü ve çaresizlik içinde bulunmak (EKE: II/412; MAT: 241).

Yâr 'aksin görüp âyînede kıldı yaka çâk

'Aksi hem yârı görüp çâk-i girîbân itdi (G.561/4)

Yakasına yapışmak (G.428/1, M.403): Usandıracak denli ve sürekli bir biçimde ondan bir şey istemek; 1srarla bir şeyler sorup öğrenmek; dövüşmek için onu tutup bırakmamak (ÖAA: II/1102; EKE: II/412; IP: II/891; AP: 790; MES: II/1178; MAT: 242).

Yakayı kurtaramamak (G.510/2): Elinden kurtulamamak (EKE: II/412).

Yalın yüzlü (G.89/1, G.346/4, G.527/4, M.203): Parlak yüzlü, güzel, gösterişli, alımlı (EKE: II/415).

Bir dilber-i âhen-dil bir hûb yalıñ yüzlü

Cân virse n'ola cânâ dil hançerüñ üstinde (G.495/3) 
Yanıp yakılmak (G.281/2, G.491/5): Çok üzücü ve derin bir acı ile sızlanmak, yürekten yanmak; derdini anlatıp şikayet etmek (ÖAA: II/1106; EKE: II/417-418; İP: II/898; AP: 795; MES: II/1188; MAT: 244).

Yara açmak (G.161/2, G.516/3, M.141, M.229/1): Vücutta yara oluşmasına sebep olmak; büyük acı ve üzüntü vermek, ruhen yaralamak (ÖAA: II/1107; EKE: II/419; İP: II/899; AP: 796; MES: II/1190)

Yarım ağızla: Bir şeyi geçiştirerek dile getirmek; tam istekli olmayarak yarı ister yarı istemez biçimde, içten gelmeyerek (ÖAA: II/1108; EKE: II/419; İP: II/901; AP: 798; MES: II/1192; MAT: 245).

Nîm-besteyle bu ben hastasını itmedi yâd

Yarım agızla beni añmadı ol gonca-dehân (G.380/4)

Yas tutmak: bk. Matem tutmak.

Yaş dökmek (G.63/5, G.70/3, G.214/3, G.272/2, G.323/3-5, G.340/1, G.388/2, G.412/4, G.426/1, G.513/1): Ağlamak, gözlerinden yaş damlamak (ÖAA: II/1109; EKE: II/420; IP: II/903; AP: 800; MES: II/1194).

Yaşı kurumak (G.323/1): Çok ağlamaktan gözlerinden yaş gelmez olmak (EKE: II/420).

Yedi kat yere geçmek (G.304/2): Çok utanmak, mahcup olmak (EKE: II/422; MES: II/1201).

Yedi kat yerin dibine geçmek: bk. Yedi kat yere geçmek.

Yele vermek: Boş yere dağıtmak, savurmak, boşa harcamak (ÖAA: II/1113; EKE: II/423-424; IIP: II/908; AP: 803; MES: II/1202; MAT: 246).

Yile virdi Emriyâ âhum gubâr-ı cismümi

'Azm-i kûy-ı yâr idersem görmeye kimse tozum (M.318/3)

Yeler onmaz: Sürekli koşuşturan, kalıcı bir iş yapmayan pek onmaz ve iyi kazanç elde edemez, iflah olmaz (ÖAA: II/1113; IP: II/909; AP: 803; MES: II/1202; MAT: 246). 
Emriyâ zülf-i perîşânina el urmak neden

Ol perî-şânuñ sabâ gibi yiler oñmaz levend (G.71/5)

Yer bulmak (G.415/3): Bir yere yerleşmek, oturacak yer sağlamak (EKE: II/424; MES: II/1205; MAT: 247).

Yer etmek (G.100/5, G.423/2, M.131/1, M.244/2, M.289/4): İz bırakmak; iyice yerleşmek; yer tutmak (ÖAA: II/1115; EKE: II/424; IP: II/914; AP: 806; MES: II/1206; MAT: 249).

Yer öpmek (G.127/4): Önemli bir kimsenin veya büyüğün önünde eğilmek, temenna etmek (ÖAA: II/1117; EKE: II/424; İP: II/918; AP: 810; MES: II/1206; MAT: 250).

Yere çalmak (G.347/3, G.543/4): Yere atmak veya vurmak, yere fırlatmak; haşlamak, hakaret etmek (EKE: II/425; İP: II/913; MES: II/1208).

Yere geçmek/batmak (M.124/1): Yok olmak; çok utanmak (ÖAA: II/1115; EKE: II/425-426; İ: II/913; AP: 806; MES: II/1208).

Yere göğe koymamak: bk. Ayağını yere koymamak.

Yerin kulağı var: Gizli olarak söylenen bir söz umulmadık bir biçimde başkalarınca duyulabilir (EKE: II/426; İP: II/917; MES: II/1209).

Beñzetme nakş-ı pây-ı seg-i yâra yir gülin

Nâ-geh işide incine yirüñ kulagı var (M.68/2)

Yerine geçmek (G.486/3): Yerini almak; bulunmayan bir nesnenin veya kavramin yerine kullanılabilmek (ÖAA: II/1116; EKE: II/426; IIP: II/915; AP: 808; MES: II/1211).

Yerine koymak (G.355/2): Öyle kabul etmek, gibi görmek; kırılan, kaybolan veya elden çıkan bir şeyin benzerini sağlamak (ÖAA: II/1116; EKE: II/427; IP: II/916; AP: 808; MES: II/1211).

Yerle bir etmek: bk. Hâk ile yeksan eylemek, Hâke yeksan eylemek.

Yıldızı alışmamak: Yıldızı barışmamak, anlaşamamak.

Katre-i eşküm girür yire gider çarha şerer

Yaşum ile âhumuñ Emrî alışmaz kevkebi (G.523/5) 
Yıldızı düşük (G.526/3): Bahtsız, talihsiz; gözden düşmüş (ÖAA: II/1119; EKE: II/429; IP: II/921; AP: 812; MES: II/1215; MAT: 251).

Subha dek agladuk bu şeb togmadı mâh-pâremüz Yılduzumuz düşük imiş işlemedi sitâremüz (G.221/1)

Yok yere (G.143/5, G.353/1, M.292/1): Boşuna, boşu boşuna, gereği yokken (ÖAA: II/1121; EKE: II/430; İP: II/922; AP: 814; MES: II/1218; MAT: 252).

Yol etmek (M.158/4): Bir yere sürekli olarak gitmek (ÖAA: II/1122; EKE: II/431; AP: 816; MES: II/1220).

Yol göstermek (G.118/4): Ne yapılacağını, nasıl davranılacağını öğretmek; öğüt vermek; yardımda bulunmak; akıl vermek (ÖAA: II/1122; EKE: II/431; IPP: II/924; AP: 816; MES: II/1220).

Yol tutmak (G.220/2): Belli bir yol izlemek; yaşayışını, davranışlarını kendine göre bir düzen içinde sürdürmek; yoldan geçenlere engel olmak (ÖAA: II/1123; EKE: II/431; IP: II/925; AP: 817; MES: II/1221; MAT: 256).

Yola/yollara düşmek (G.491/4): Bir yere gitmek üzere bulunduğu yerden ayrılip yol almaya başlamak; önemli bir durumun gerektirmesiyle zorunlu olarak yola çıkmak ya da yol yol dolaşmak (ÖAA: II/1121; EKE: II/431-432; IP: II/923; AP: 815; MES: II/1222).

Yollarda kalmak (G.543/1): Varacağ1 yere birtakım engeller yüzünden zamanında gidememek; yolda zaman yitirmek (EKE: II/433; IP: II/925; AP: 817; MES: II/1223-1224).

Yoluna dökmek (G.334/4): Yolu üstüne sermek; uğruna feda etmek.

Yolunda pâymâl olmak: Uğruna kendini feda etmek.

Kâş ey dil şikeste-hâl olsañ

'Iş̧ yolında pâymâl olsañ (G.288/1)

Yolunda toprak (hâk) olmak (G.339/1, M.422): Yolunda kendini feda etmek, uğrunda ölmek. 
Şâyed ki atı ugraya üstüme meyl ide

Hâk olayın yolında ki bitsün giyâhlar (G.88/2)

Yükünü çekmek (M.306/3): Bütün ağırlığını taşımak, her türlü sıkıntıya ve eziyete katlanmak (İP: II/933).

Yüreği ağzına gelmek (M.306/4): Ansızın, beklenmedik bir durum karşısında kalarak çok korkmak, heyecanlanmak veya ürkmek (ÖAA: II/1129; EKE: II/439; IP: II/934; AP: 825; MES: II/1234; MAT: 258).

Yüreği kopmak (G.432/4): Çok korkmak, yüreği kalkmak, heyecanlanmak (EKE: II/440; AP: 826; MAT: 259).

Yüreği oynamak (G.292/1, G.409/2): Birdenbire heyecanlanmak veya korkmak (ÖAA: II/1131; EKE: II/440-441; İP: II/937; AP: 827; MES: II/1237; MAT: 260).

Yüreği/içi yanmak (G.208/3): Büyük bir felakete uğramak; büyük bir acı duyarak çok üzülmek; çok susamak (ÖAA: II/1131; EKE: II/442; IIP: II/485; AP: 828; MES: II/1238; MAT: 149). Аyrıca bk. Canına ateş düşmek.

Yüz burtarmak: Yüz ifadesi ile memnun olmadığını göstermek, yüzünü buruşturmak (ÖAA: II/1137; Dilçin 1983, 41; EKE: II/455; İP: II/944; AP: 835; MES: II/1249).

Sanma pür-mevc oldı bahr öykündügiyçün yaşuma

Bâd-ı âhum pek tokındı aña burtardı yüzin (M.346/3)

Yüz çevirmek/döndürmek (G.164/4, G.270/5, G.324/2, G.435/5, M.22/1): Dostluğu, yakınlığ1 ve ilgiyi kesmek, ilgilenmemek (ÖAA: II/1132; EKE: II/446-447; İP: II/940; AP: 830; MES: II/1241; MAT: 261).

Yüz dürmek (G.513/6): Surat asmak, yüz buruşturmak (MAT: 262).

Gül 'andelîbe karşu yüzin dürdi Emriyâ

Kim bile jâleler ne koyupdur kulagına (G.426/5)

Yüz göstermek (G.68/3, Muh.1/IV, G.278/2): Ortaya çıkmak, kendini göstermek (ÖAA: II/618; EKE: II/447; IPP: II/151; AP: 830; MES: II/1242; MAT: 263). 
Yüz karalığı (etmek): Utanılacak bir şey yapmak (EKE: II/447; MES: II/1242).

Ne yüz karalıgın itdi bu Emrî-i miskîn

K'özüñden eyledün anı cüdâ o kâkül-vâr (G.177/5)

Yüz suyu dökmek (G.56/5, G.442/2, M.328/1): Gururunu ayaklar altına alacak kadar çok yalvarmak; kendini zorlayarak ricada bulunmak (ÖAA: II/1133; EKE: II/448-449; IP: II/941; AP: 831; MAT: 263).

Sarsar nesîm-i bâg $u$ düşer sanma jâleler

Yüzi suyın döker yire 'ışkuñda lâleler (M.74/1)

Yüz sürmek (G.57/2, G.78/1, G.89/2, G.101/2, G.266/1, G.272/4, G.333/4, G.338/3, G.474/4, G.486/1, M.205): Kutsal veya saygın birinin huzuruna çıkarken ayağına doğru eğilmek, saygı göstermek (ÖAA: II/1134; EKE: II/449-450; İP: II/941; AP: 831; MES: II/1242-1243; MAT: 264).

Suçın bagışla Emrînüñ tapuña yüz süre geldi

İder yüz meskenet birle tevâzu'lar gedâlıklar (G.201/5)

Yüz tutmak (G.23/1, G.100/4): Olgunlaşmaya başlamak, olmak üzere bulunmak; zamanla şekil ve renk değiştirmek; yönelmek (ÖAA: II/1134; EKE: II/450; IP: II/941; AP: 831; MES: II/1243; MAT: 264).

Yüz tutup cevre dime mihr ü meh olmaz baña râm

Mâh avcuñda durur mihr elüñ altında senüũ̃ (G.270/2)

Yüz vurmak (G.424/1): Sığınmak, yardım dilemek, yönelmek; kutsal ve değerli saymak; saygı göstermek; başvurmak (EKE: II/451; MES: II/1243).

Gör harîm-i hüsn içre hâl-i 'anber-fâmını

San Bilâl urdı yüzini Ka'benüñ dîvârına (G.433/5)

Yüz yüze gelmek: bk. Yüze yüz gelmek.

Yüze yüz gelmek (G.172/3): Birdenbire karşılaşmak, karşısına çıkmak; bir araya gelmek (ÖAA: II/914; IP: II/947; AP: 838; MES: II/1243; MAT: 269). 
Yüze yüz olmak (M.172/1): Birdenbire karşılaşmak, karşısına çıkmak; bir araya gelmek (ÖAA: II/914; IIP: II/947; AP: 838; MES: II/1243; MAT: 269).

Yüzü kara (G.90/4, G.469/3, G.494/3, G.505/1): Utanılacak bir durumu olan (ÖAA: II/1135; EKE: II/452-453; İP: II/942; AP: 832; MES: II/1245; MAT: 265).

Yüzü kararmak: Yaptığı işten veya bir hatadan dolayı utanmak, sıkılmak (EKE: II/455; İP: II/942; AP: 833). Ayrıca bk. Yüzü k1zarmak.

Kendüyi kâkül-i müşgînüne teşbîh idicek

Bu hatâ ile karardı yüzi müşg-i Hotenü̃ (G.271/2)

Yüzü kızarmak (G.366/4): Yaptığ1 işten veya bir hatadan dolayı utanmak, sıkılmak (EKE: II/455; IP: II/942; AP: 833). Ayrıca bk. Yüzü kararmak.

Yüzü sararmak (K.1/31, G.12/3, G.12/6, G.219/3, G.493/2, G.517/5): Sıkıntıdan, üzüntüden veya korkudan yüzünün rengi değişmek (EKE: II/453; İP: II/173; MES: I/202). Ayrıca bk. Benzi sararmak.

Yüzü sulu: Güzel, asil yüzlü, yüzü nurlu (MAT: 270).

Emriyâ jâle-i ter gül ruhını zeyn itmiş

Hûblar içre kanı ancılayın yüzi sulu (G.419/5)

Yüzü yerde (olmak): Mahcup olarak, utanarak; alçakgönüllü (ÖAA: II/1139; EKE: II/453-454; IP: II/946; AP: 837; MES: II/1247).

Olsa ey gonca yüzi yirde n'ola yir gülinün

Reng virmişdür ana mihr-i 'izâruñ kat kat (M.37/2)

Yüzüne bakılmaz (M.280): Sevimsiz, çok çirkin (EKE: II/454; IP: II/943; AP: 834; MES: II/1248).

Yüzüne bakmamak (G.110/2, G.497/1): Ciddi görmemek, önem ve değer vermemek; bir kimseye darılmak, onunla bir daha konuşmamak (ÖAA: II/1136; EKE: II/454; IP: II/943; AP: 834; MES: II/1248; MAT: 266). 
Yüzüne (karşı) söylemek (M.335/1): Karşısındakinden hiç çekinmeden söylemek; arkasından konuşmamak (ÖAA: II/1136; EKE: II/455; IP: II/944; AP: 834; MES: II/1249; MAT: 266).

Yüzüne vurmak/çarpmak (bir şeyi) (G.61/5, M.388/1): Kabahatini, kusurunu yüzüne karşı söyleyip kendisini ayıplamak (ÖAA: II/1137; EKE: II/455; İP: II/943; AP: 835; MES: II/1249; MAT: 266).

Yüzünü ekşitmek: bk. Yüz burtarmak.

Zahmet vermek (G.62/4): Yük olmak, sıkıntı vermek, eziyet etmek (İP: II/949; MES: II/1253).

Zayıf düşmek (G.204/5, G.427/4): Zayıflamak, güçsüzleşmek; saygınlığını veya maddî gücünü yitirmek (İP: II/953; AP: 840; MES: II/1257).

Zebunu olmak: Birine tutulmak, çok sevmek, aşırı düşkün olmak (İP: II/954).

Meydân-ı 'ışk içinde Mecnûnı añma baña

Er midür ol kim ola bir 'avratuñ zebûnı (G.548/3)

Zerreye saymamak: Zerre kadar değer vermemek, değersiz görmek.

Âfitâb-ı 'âlem-ârâsin tenezzül eyleme

Zerre-i nâçîüũe sayma o mâh-ı enveri (G.517/2)

Zeval bulmak: bk. Zevale ermek.

Zevale ermek/erişmek (G.186/3, G.297/2, G.538/4): Sona ermek, bozulup yok olmak, çökmek (IIP: II/956; MES: II/1259).

Zevali gelmek (M.282/2): Yok olmas1, sona ermesi, batmas1 yaklaşmak.

Zincire çekmek/vurmak (G.124/5): Zincire bağlamak; birinin elini, ayağını ya da boynunu zincirle bağlamak (EKE: II/458; İP: II/960; MES: II/1266).

Zindan etmek (G.159/4): Bir yeri yaşanmaz duruma getirmek, zevk alınmaz hâle sokmak; dünyasını karartmak (İP: II/960; MES: II/1267). 
Zindan olmak (G.209/1): Yaşanmaz duruma gelmek; dünyası kararmak; çok karanlık bir duruma gelmek (ÖAA: II/1144; IP: II/960; AP: 845; MES: II/1267).

\section{SONUÇ}

1. Emrî Divanı'nda 541 farklı deyimin toplam 1031 defa kullanıldığ1 görülmüştür. $\mathrm{Bu}$ sayı eserin deyimler bakımından zengin olduğunu gösterir. Bu deyimlerin bazılarının kapsamlı deyim sözlüklerinde bile yer almadığı bu çalışmada ortaya konmuştur.

2. Muammaları ve tarih düşürmedeki ustalığı ile tanınan Emrî, deyimleri yaygın ve etkili bir şekilde kullanmasıyla da dikkati çekmektedir.

3. Şairin eserindeki deyim zenginliği Türkçeye hâkim olduğunu gösterir.

4. Divan'da vezin ve kafiye zaruretiyle zaman zaman deyimi oluşturan kelimelerin yerlerinin değiştiği ve deyimi oluşturan kelimeler arasina kelime ya da kelimelerin girdiği görülmektedir. Bazen deyimin vezin, kafiye veya söz sanatları için değiştirildiği, kısaltıldığı örneklere rastlanmaktadır. Şair, yardımcı fiil kullandığı deyimlerin yardımcı fiilini zaman zaman değiştirip farklı bir yardımcı fiil kullanmıştır.

5. Deyimlerde genellikle Türkçe kelimeler tercih edilse de bazen kelimelerin Arapça ve Farsça karşılıkları da kullanılmıştır.

6. Deyim bakımından oldukça zengin olan Divan'da atasözlerinin az sayıda yer alması dikkati çekicidir.

7. Divan şiirinde deyimler konusunda hem makale hem sözlük düzeyinde çalışmalara ihtiyaç olduğu ortadadır. Buradan hareketle divan şiiri metinlerinin deyimler açısından etraflıca incelenmesi hem bundan sonraki sözlük çalışmalarına kaynak sağlayacaktır. 


\section{Kaynakça}

AKSOY Ömer Asım (1984), Atasözleri ve Deyimler Sözlü̆̆̈̈ I-II, Ankara: İnkılâp Yay.

ÇAVUŞOĞLU Mehmed (1998), "Gen Yakadan", Divanlar Arasında, Ankara: Akçă̆ Yay., s. 98-104.

ÇETİNKAYA Ülkü (2009), "Divan Şiirinde Çok Başlu (Ziyade-Ser) Deyimi Üzerine", Turkish Studies, S. 4/2 Winter, s. 226-245.

DİLÇìN Cem (1983), Yeni Tarama Sözlüğü, Ankara: TDK Yay.

EYÜBOĞLU E. Kemal (1973), On Üçüncü Yüzyıldan Günümüze Kadar Şiirde ve Halk Dilinde Atasözleri ve Deyimler II, Deyimler-(Tâbirler), İstanbul: Doğan Kardeş Matbaacıllk.

Millî Kütüphane Başkanlığ1 (1997): Türk Atasözleri ve Deyimleri I-II, İstanbul: MEB Yay.

PARLATIR İsmail (2008), Atasözleri ve Deyimler Sözlüğ̈̈ I-II, Ankara: Yarg1 Yay.

PÜSKÜLLÜOĞLU Ali (2006), Türkçe Deyimler Sözlü̆̆̈̈, Ankara: Arkadaş Yay.

SARAÇ M. A. Yekta, Emrî Dîvânı, Kültür ve Turizm Bakanlığı ekitap: Ankara, http://ekitap.kulturturizm.gov.tr/dosya/1-128327/h/ giris-emridivani.pdf, http://ekitap.kulturturizm.gov.tr/ dosya/1128328/h/emridivani.pdf, (01.07.2011).

SARAÇ M. A. Yekta (1997), "Emrî́nin Hayatı ve Edebî Kişiliği", İstanbul Üniversitesi Türkiyat Mecmuası, c. 20, s. 315-331.

Saraç M. A. Yekta (1995), "Emrî, Emrullah", DİA XI, İstanbul: Türkiye Diyanet Vakfı Yay., s. 164.

SARAÇBAŞI M. Ertuğrul (2010), Örnekleriyle Büyük Deyimler Sözlüğü I-II, İstanbul: Yap1 Kredi Yay.

TANYERİ M. Ali (1999), Örnekleriyle Divan Şiirinde Deyimler, Ankara: Akçă̆ Yay.

Türkçe Sözlük I-II (1998), Ankara: TDK Yay.

YILMAZ Ozan (2009), "Klasik Türk Edebiyatı'nda Bir Deyim: Ter Düşmek", Türk Kültürü İncelemeleri Dergisi, S. 21, s. 155-170. 